\title{
Integrated hydrometeorological, snow and frozen-ground observations in the alpine region of the Heihe River Basin, China
}

\author{
Tao Che ${ }^{1,2}$, Xin Li ${ }^{2,3}$, Shaomin Liu ${ }^{4}$, Hongyi Li ${ }^{1}$, Ziwei Xu ${ }^{4}$, Junlei Tan ${ }^{1}$, Yang Zhang ${ }^{1}$, Zhiguo Ren ${ }^{1}$, \\ Lin Xiao ${ }^{1}$, Jie Deng ${ }^{1,6}$, Rui Jin ${ }^{1,2}$, Mingguo $\mathrm{Ma}^{5}$, Jian Wang ${ }^{1}$, and Xiaofan Yang ${ }^{4}$ \\ ${ }^{1}$ Heihe Remote Sensing Experimental Research Station, Key Laboratory of Remote Sensing of Gansu \\ Province, Northwest Institute of Eco-Environment and Resources, Chinese Academy \\ of Sciences, Lanzhou 730000, China \\ ${ }^{2}$ Center for Excellence in Tibetan Plateau Earth Sciences, Chinese Academy \\ of Sciences, Beijing 100101, China \\ ${ }^{3}$ National Tibetan Plateau Data Center, Institute of Tibetan Plateau Research, Chinese Academy of Sciences, \\ Beijing 100101, China \\ ${ }^{4}$ State Key Laboratory of Earth Surface Processes and Resource Ecology, Faculty of Geographical Science, \\ Beijing Normal University, Beijing 100875, China \\ ${ }^{5}$ Chongqing Engineering Research Center for Remote Sensing Big Data Application, School of Geographical \\ Sciences, Southwest University, Chongqing 400715, China \\ ${ }^{6}$ Jiangsu Center for Collaborative Innovation in Geographical Information Resource Development and \\ Application, Nanjing 21003, China
}

Correspondence: Xin Li (xinli@itpcas.ac.cn)

Received: 22 January 2019 - Discussion started: 25 February 2019

Revised: 23 May 2019 - Accepted: 15 August 2019 - Published: 30 September 2019

\begin{abstract}
The alpine region is important in riverine and watershed ecosystems as a contributor of freshwater, providing and stimulating specific habitats for biodiversity. In parallel, recent climate change, human activities and other perturbations may disturb hydrological processes and eco-functions, creating the need for nextgeneration observational and modeling approaches to advance a predictive understanding of such processes in the alpine region. However, several formidable challenges, including the cold and harsh climate, high altitude and complex topography, inhibit complete and consistent data collection where and when it is needed, which hinders the development of remote-sensing technologies and alpine hydrological models. The current study presents a suite of datasets consisting of long-term hydrometeorological, snow cover and frozen-ground data for investigating watershed science and functions from an integrated, distributed and multiscale observation network in the upper reaches of the Heihe River Basin (HRB) in China. Meteorological and hydrological data were monitored from an observation network connecting a group of automatic meteorological stations (AMSs). In addition, to capture snow accumulation and ablation processes, snow cover properties were collected from a snow observation superstation using state-of-the-art techniques and instruments. High-resolution soil physics datasets were also obtained to capture the freeze-thaw processes from a frozen-ground observation superstation. The updated datasets were released to scientists with multidisciplinary backgrounds (i.e., cryospheric science, hydrology and meteorology), and they are expected to serve as a testing platform to provide accurate forcing data and validate and evaluate remote-sensing products and hydrological models for a broader community. The datasets are available from the Cold and Arid Regions Science Data Center at Lanzhou (https://doi.org/10.3972/hiwater.001.2019.db, Li, 2019).
\end{abstract}




\section{Introduction}

Water resources in the alpine region are headwaters to sustain downstream ecosystems. However, perturbations induced by nature or climate change and human activities in recent years have significantly altered hydrological processes and ecofunctions ( $\mathrm{Li}$ et al., 2018a). Accurate estimation and prediction of hydrological processes and their key impacts has since become crucial (Pomeroy et al., 2007; Chen et al., 2014; Li et al., 2018b). Process-based alpine hydrological models, e.g., the Geomorphology-Based Eco-Hydrological Model (GBEHM; Yang et al., 2015); the Water and Energy Budget-based Distributed Hydrological Model (WEB-DHM; Wang et al., 2010); the Cold Regions Hydrological Model (CRHM; Pomeroy et al., 2007), and the Cryospheric Basin Hydrological Model (CBHM; Chen et al., 2018), are feasible for advancing a fundamental understanding of the hydrological cycle and its individual components, i.e., separating the contributions from processes such as snow melting, freezethaw, precipitation, evapotranspiration and runoff by determining their spatiotemporal distributions across scales. Unfortunately, the scarcity of observation data in the alpine region, due to the difficulties of access and technological barriers, has hindered alpine hydrological modeling and associated research yet has motivated the development of nextgeneration ecosystem observation networks and experiments (Hrachowitz et al., 2013). In comparison with observations, using remote-sensing data combined with data assimilation could improve the prediction of hydrological processes (Schmugge et al., 2002; Clark et al., 2006). However, due to the complexities of the Earth system, there exist various sources of uncertainties in remote-sensing data (especially in the alpine region), which have to be validated and calibrated (Hall and Riggs, 2007; Jackson et al., 2010; Che et al., 2012; Frei et al., 2012; Dai et al., 2017). In summary, to fill the knowledge gap and promote alpine region hydrology research, an integrated, distributed and multiscale observation dataset is essential and expected to provide accurate forcing data for hydrological modeling, validate remotesensing data, allow the evaluation of distributed models, and ultimately improve a predictive understanding of alpine hydrological processes and ecosystem functions.

In alpine hydrology, in addition to consistent hydrometeorological data obtained from distributed meteorological stations, snow cover and frozen-ground are two important indexes and driving forces that influence hydrological processes (Cline, 1997; Dewalle and Rango, 2008; Walvoord and Kurylyk, 2016). The maximum snow water equivalent (SWE) before ablation determines the storage of snowmelt - a major source of freshwater in the alpine region (Chahine, 1992), while freeze-thaw cycles (FTCs) and soil moisture within the active layer alter water infiltration and, consequently, surface runoff and groundwater (Shanley and Chalmers, 1999; Hardy et al., 2001). Several representative snow observation stations were established throughout the world to collect snowpack data during seasonal changes at the catchment or watershed scale (Dewalle and Rango, 2008; Kinar and Pomeroy, 2015) in the USA (the Reynolds Creek experimental watershed, Nayak et al., 2010; the Sleepers River Basin, Pellerin et al., 2012; the Hubbard Brook Basin, Hardy et al., 2001; the Loch Vale, Balk and Elder, 2000; the Green Lakes Valley, Caine, 1992), Canada (the Marmot Creek Research Basin, DeBeer and Pomeroy, 2009) and Europe (the Swiss Alps, Davos, Beniston et al., 2003; the Col de Porte experimental site, Morin et al., 2012). To promote alpine hydrology research, the International Network for Alpine Research Catchment Hydrology (INARCH) was launched in 2015 by the Global Energy and Water Exchanges (GEWEX) project of the World Climate Research Programme (WCRP), involving 18 catchments around the world (Pomeroy et al., 2015). The INARCH has since connected individual observatories into an international network and data-sharing platform to lead frontier research on alpine region hydrometeorology and snow observation. Another community-based observation network, the Circumpolar Active Layer Monitoring (CALM) network, was initiated in the early 1990s to observe the response of the active layer and near-surface permafrost to climate change (Brown et al., 2000). The sites of the CALM network are located not only in the Arctic and Antarctic regions but also in several midlatitude mountainous regions. The observation infrastructure is designed to include standard active layer and near-surface permafrost measurements, with snow cover, soil moisture and ground subsidence measured simultaneously at selected sites (Brown et al., 2000). In addition, the Global Terrestrial Network for Permafrost (GTN-P) is the primary international program targeted at monitoring permafrost parameters. GTN-P was developed in the 1990s by the International Permafrost Association (IPA) under the Global Climate Observing System (GCOS) and the Global Terrestrial Observing System (GTOS), with the long-term goal of obtaining a comprehensive understanding of the spatial structure, trends and variability of changes in the active layer thickness and permafrost temperature (Streletskiy et al., 2017). The CALM and GTN-P networks have shared stations and are considered two representative initiatives focusing on frozen-ground observation.

The Heihe River Basin (HRB) is the second-largest inland river basin in China and is known for its heterogeneous landscapes, diverse ecosystems, unique geographical characteristics and climate change over recent decades. The HRB is mainly composed of glaciers, snow cover, frozen ground, alpine meadows, forests, irrigated crops, riparian ecosystems and deserts (distributed along an altitudinal gradient), which makes it an ideal field site for hydrometeorological research and has motivated and initiated the establishment of China's first basin-scale integrated observatory network (Li et al., 2009, 2013, 2017; Liu et al., 2018). As a major component of the ecohydrological processes in the arid and semiarid HRB, alpine hydrological processes, es- 
pecially those related to snow cover and frozen ground in the upper reaches, have marked impacts on runoff in the mountainous regions, which then regulate agricultural development in the middle reaches and the ecosystems of the lower reaches (Li et al., 2018b). To characterize the dynamic alpine hydrological processes influenced by natural variability and recent human activity, extensive research has been conducted in the upper HRB, including both observation and modeling efforts. Nevertheless, long-term observations in the upper reaches of the HRB were often conducted either in a specific area (e.g., small catchment, Chen et al., 2014) or focused on selected elements (e.g., frozen ground, Peng et al., 2016; forest hydrology, He et al., 2012 and Wang et al., 2013). Several distributed hydrological models have been utilized to predict altered hydrologic processes under various climate scenarios (Wang et al., 2010; Zhang et al., 2017; Gao et al., 2018). However, the above modeling efforts suffered from (1) the availability of the forcing data (only two weather stations operated by the Chinese Meteorological Administration functioned in the upper reaches of the HRB) and (2) a lack of high-quality snow and frozenground data for parameterization. To overcome the above issues, a comprehensive observation network for alpine hydrology was built in the upper reaches of the HRB starting in 2013 during the Heihe Watershed Allied Telemetry Experimental Research (HiWATER, Li et al., 2013). Composed of seven standard automatic meteorological stations (AMSs), one snow superstation and one frozen-ground superstation, the observation network serves as an integrated research platform aiming to provide prominent datasets (e.g., hydrometeorology, snow and frozen ground) of the hydrometeorological processes in the upper reaches of the HRB, which is expected to support alpine region hydrological model development and simulations, along with remote-sensing observations. Since 2015, the HRB alpine observation network has joined the INARCH (http://www.usask.ca/inarch/, last access: 5 September 2019), which also built a solid foundation for international collaborations.

This paper introduces the infrastructure of the integrated alpine hydrology observation network in the HRB and the complete datasets collected in recent years. The experimental site and design are summarized in Sect. 2. A detailed description of hydrometeorological, snow, and frozen-ground observations is given in Sect. 3, with subsequent discussion and data analysis. The data availability and access are provided in Sect. 4, and the conclusions, with future perspectives, are summarized in Sect. 5.

\section{An integrated hydrometeorological, snow and frozen-ground data observation network in the upper reaches of the HRB}

\subsection{Site descriptions}

The integrated hydrometeorological, snow and frozenground data observation network was established in an alpine region in the semiarid region of northwestern China, with a size of $10,009 \mathrm{~km}^{2}$, ranging from 1674 to $5108 \mathrm{~m}$ in altitude $\left(37.72-39.09^{\circ} \mathrm{N}, 98.57-101.16^{\circ} \mathrm{E}\right.$, Fig. 1). It is located in the upper reaches of the HRB $\left(143200 \mathrm{~km}^{2}\right)$ and the Qilian Mountains (at the intersection of the Qinghai-Tibet Plateau, QTP, and the Mongolian Plateau, MP). The unique geographical characteristics of the HRB (high altitude, complex terrain, various ecosystems and harsh climate), i.e., the widespread snow cover and frozen ground, make it an ideal field site for alpine research yet they present great challenges in terms of observation. Detailed descriptions of the study site are provided as follows.

The study site exhibits complex and dynamic hydrometeorological characteristics. The western region is dominated by the midlatitude westerlies, while the eastern region is influenced by the southwestern and southeastern Asian monsoons. Due to its regional atmospheric circulation and topography, the annual precipitation in the area decreases from the east to the west, with an average of $510 \mathrm{~mm}(454.7 \mathrm{~mm}$ rainfall and $65.3 \mathrm{~mm}$ snow) (Li et al., 2018b). From low to high altitudes, the land surface of the study area is highly heterogeneous, including alpine grasslands (dominant), alpine shrubs, alpine meadows, tundra, deserts and forest steppes. The soil texture is mainly composed of loam, with silt loam near the surface and sandy soil in deeper layers. In the area covered by grasses and forests, the organic content is very high within the top $30 \mathrm{~cm}$ of the soil layer, which impacts the energy and water exchange between the land and atmosphere (Chen et al., 2012). The land surface is frozen during the winter across the entire experimental area. The lower limit of the permafrost is between approximately 3700 and $3800 \mathrm{~m}$, while the rest is seasonally frozen ground. In recent years, due to climate warming, permafrost degradation has significantly affected runoff and the carbon cycle (Peng et al., 2016; Gao et al., 2018). Snow cover is widely distributed, with unique characteristics in the study area. In the high-altitude mountainous regions (elevation $>3800 \mathrm{~m}$ ), influenced by the local microclimate and low temperature, snowfall could occur in any season. Temporary snow is the major snow cover type in the region at middle and low elevations because strong solar radiation and high air temperature lead to rapid melting and sublimation of the snow. In January and February, snowfall events were rare in historical records due to the relatively low moisture in the atmosphere, while spring and autumn (i.e., March to May, October to November) are considered two main snowfall seasons. Drifting snow is also commonly observed in the region, which 

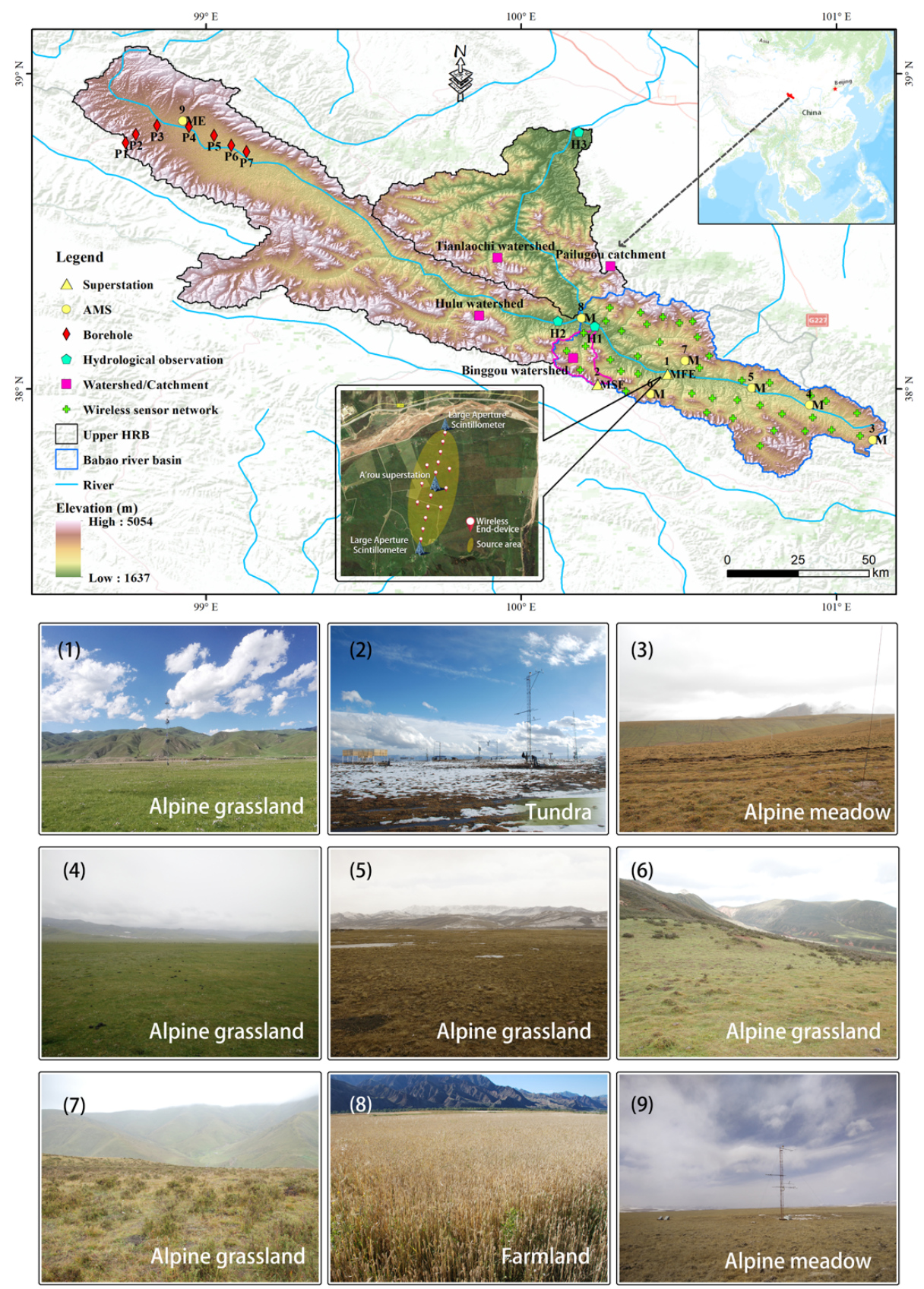

Figure 1. The integrated hydrometeorological, snow and frozen-ground data observation network located at the study site. The observation network includes seven meteorological stations $(M)$, one frozen-ground superstation $(F)$ and one snow superstation $(S)$. The frozen-ground and snow superstation observe the meteorological variables, evapotranspiration (E), and water and carbon fluxes, while the Dashalong station (No. 9) observes evapotranspiration by eddy covariance. The other observation watersheds (purple square) in the upper HRB include the Hulu watershed (Chen et al., 2014), Pailugou watershed (He et al., 2012), Tianlaochi watershed (Peng et al., 2014) and Binggou watershed (Li and Wang, 2011). There are nine boreholes in the west for permafrost observation (red diamond, Peng et al., 2016). In addition, 40 wireless sensor nodes (end device, green cross) were designed to observe soil moisture and temperature in a sub-basin and the Babao River Basin (bounded by purple polygons, more details and data can be found in Jin et al., 2014). Additionally, there are three hydrological sites in the upper HRB where the runoff was measured (blue circle). In the zoomed-in subfigure at the bottom, a pair of large aperture scintillometers (LASs) are shown on the north-facing and south-facing slopes of the A'rou frozen-ground superstation, in the middle of which 16 wireless end devices (yellow dots) were installed for soil moisture and temperature measurements. To illustrate the ecosystems in the study area, nine typical landscapes are presented as listed in Table 1. 
may lead to the redistribution of snowpack in high-elevation regions (Essery et al., 1999; Li et al., 2014).

\subsection{Observation infrastructure}

Considering the characteristics of the study site, an integrated, distributed and multiscale hydrometeorological, snow and frozen-ground data observation network has been established with seven AMSs and two superstations (Table 1), with specific scientific focus on the hydrometeorological processes at the basin (the current study site) and sub-basin (the Babao River Basin in Fig. 1) scales, as well as two key impact factors in the alpine hydrological process: snow cover and frozen ground. At the basin scale, the observation aims to collect data for investigating the meteorological driving forces and for validation of the alpine hydrological models. At the sub-basin scale, small-scale observations and measurements focus on data such as precipitation, soil temperature and moisture, which are used to develop and improve hydrologic models, as well as to validate remote-sensing products at medium to coarse resolutions (Jin et al., 2014). At the two superstations for snow cover and frozen-ground observations, remote-sensing products and land surface models can be further validated using fine-resolution data.

For hydrometeorological observation, topographic characteristics (elevation, terrain and landscape) were fully considered in the location of the stations and sites. In total, seven AMSs, as well as the frozen-ground and snow superstations (also incorporating meteorological observations), were established in the study area during the intensive observation period (IOP: 2013-2014) to obtain the spatially distributed meteorological variables. After the IOP, four typical AMSs were selected and retained for continuous observation, which is expected to provide long-term datasets. The observed meteorological variables include wind (speed and direction), air temperature, humidity, infrared temperature, air pressure, four-component radiation and precipitation. It is noted that all the sensors were installed in the same way at the same height at each station to guarantee consistency. A typical layout of the AMSs installed at the Dashalong station is shown in Fig. 2a.

Snow cover is a prominent feature in the study site. Accumulation and depletion processes were measured automatically at the Yakou snow superstation (Fig. 2b). The observed components included snow depth, snow water equivalent (SWE, measured by GammaMONitor, GMON), albedo of the snow surface and blowing (drifting) snow flux (measured by FlowCapt). Solid precipitation was recorded based on a weighing bucket precipitation gauge with a double fence intercomparison reference (DFIR) recommended by the World Meteorological Organization (WMO). In addition, meteorological variables, soil temperature and moisture were also observed.

Soil temperature and moisture were measured within six layers at each AMS, while evapotranspiration (ET) was ob- served by eddy covariance (EC) at three AMSs located in permafrost, seasonally frozen ground and a transient zone to observe freeze-thaw (FT) processes. At the sub-basin scale, a wireless sensor network (WSN) with 40 nodes was established to capture seasonal changes in soil temperature and moisture (more details and data can be found in Jin et al., 2014). At the A'rou frozen-ground superstation (Fig. 2c), soil temperature and moisture profiles were intensively measured in 18 layers to a depth of $3.2 \mathrm{~m}$ (in a nested pattern with more layers in the topsoil) to obtain the soil hydrothermal features under freeze-thaw cycles (FTCs). In addition, thermal conductivity and hydraulic conductivity in the topsoil were also measured to observe the dynamic hydrothermal processes within.

Table 2 summarizes all the variables, sensors and measuring locations at the seven AMSs, Yakou snow superstation and A'rou frozen-ground superstation.

\section{Data description}

\subsection{Meteorological data}

Distributed meteorological data were obtained from seven AMSs, most of which were built on flat ground, with two stations on the north-facing and south-facing slopes. All AMSs recorded precipitation, direction and speed of wind, air temperature and humidity, surface air pressure, upward and downward radiation of both short and long waves (four components), and land surface temperature (LST). All sensors (listed in Table 2 with manufacturers, models and specifications) were calibrated and intercompared before being mounted. The sampling frequencies, reference heights and directions of these sensors at all stations were identical to keep the consistency of the data. For more detailed observations, wind speed, air temperature and humidity were recorded at $1,2,5,10,15$ and $25 \mathrm{~m}$ at the A'rou frozenground superstation. Three eddy covariance (EC) systems were installed to measure evapotranspiration (ET) at the Yakou snow superstation (built on widely distributed permafrost), the A'rou frozen-ground superstation (built on seasonally frozen ground) and the Dashalong station (in the transition zone). In the open area around the A'rou frozenground superstation, a pair of large aperture scintillometers (LASs) was installed to measure the sensible heat flux of the land surface. Meteorological data were generally logged every $30 \mathrm{~min}$ and can be aggregated to hourly, monthly and yearly values per request (Liu et al., 2011). Steps of the AMS data processing and quality control were two-fold: (1) all the AWS data were averaged over an interval of $30 \mathrm{~min}$ for a total of 48 records per day. The missing data were denoted by -6999 ; (2) the unphysical data were rejected, and the gaps were denoted by -6999 . 


\section{(a)}

(b)
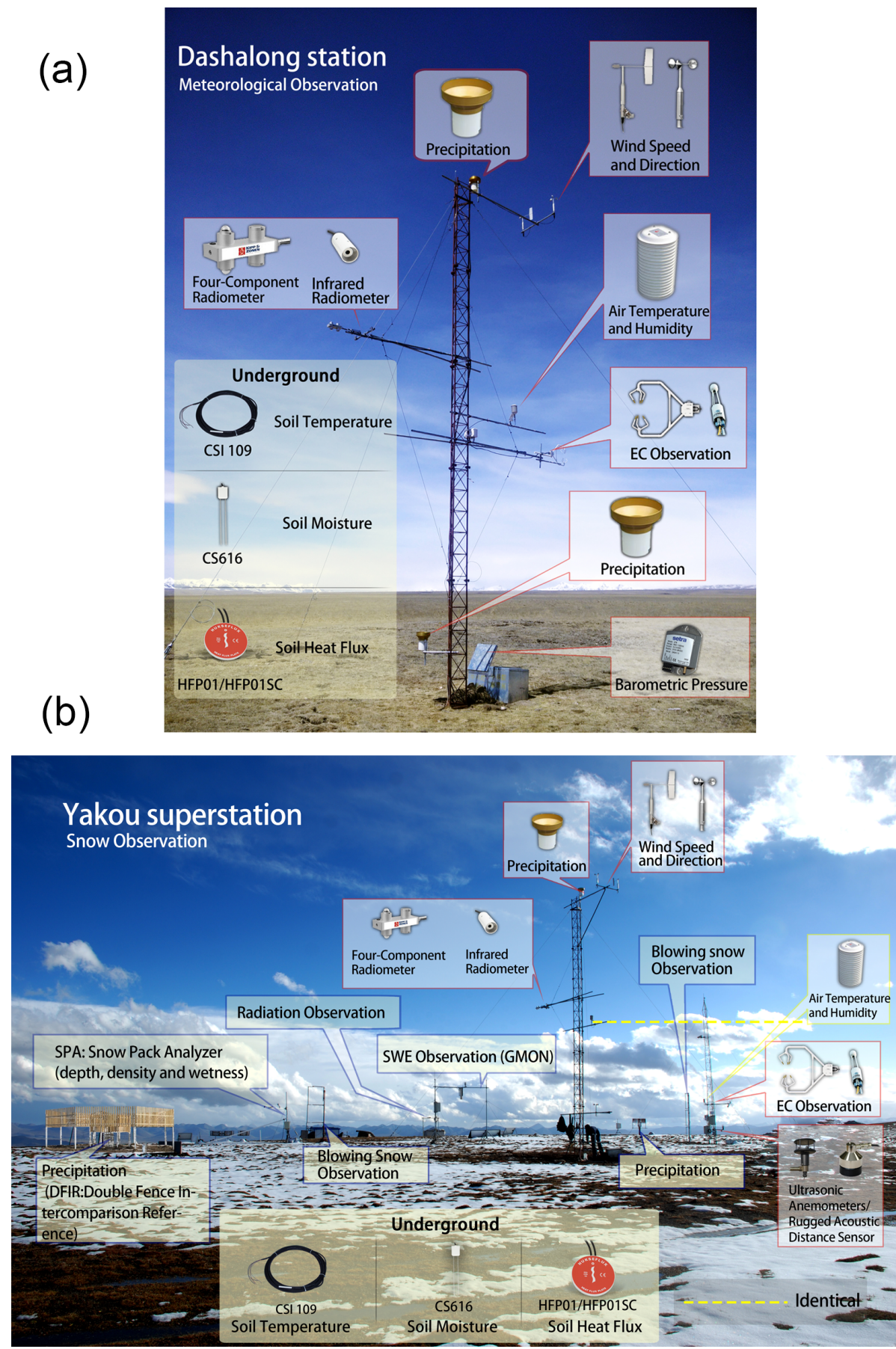

Figure 2.

\subsubsection{Air temperature and humidity}

Air temperature and humidity were monitored at a height of $5 \mathrm{~m}$ above the ground every $30 \mathrm{~min}$ during various periods at all nine stations. At the A'rou frozen-ground superstation, air temperature and humidity were observed at heights of 1 , 2, 10, 15 and $25 \mathrm{~m}$ every $30 \mathrm{~min}$ from 14 October 2012 to 31 December 2017. Consistent trends for both variables were noticed at all heights. However, air humidity showed a decreasing pattern with increasing heights. At locations other than the Yakou snow superstation, surface temperature was observed every $30 \mathrm{~min}$ from 24 June to 4 July 2014 using two sets of equipment for cross-comparison. Almost identical data were obtained between the two sets, although with variations among sites. 


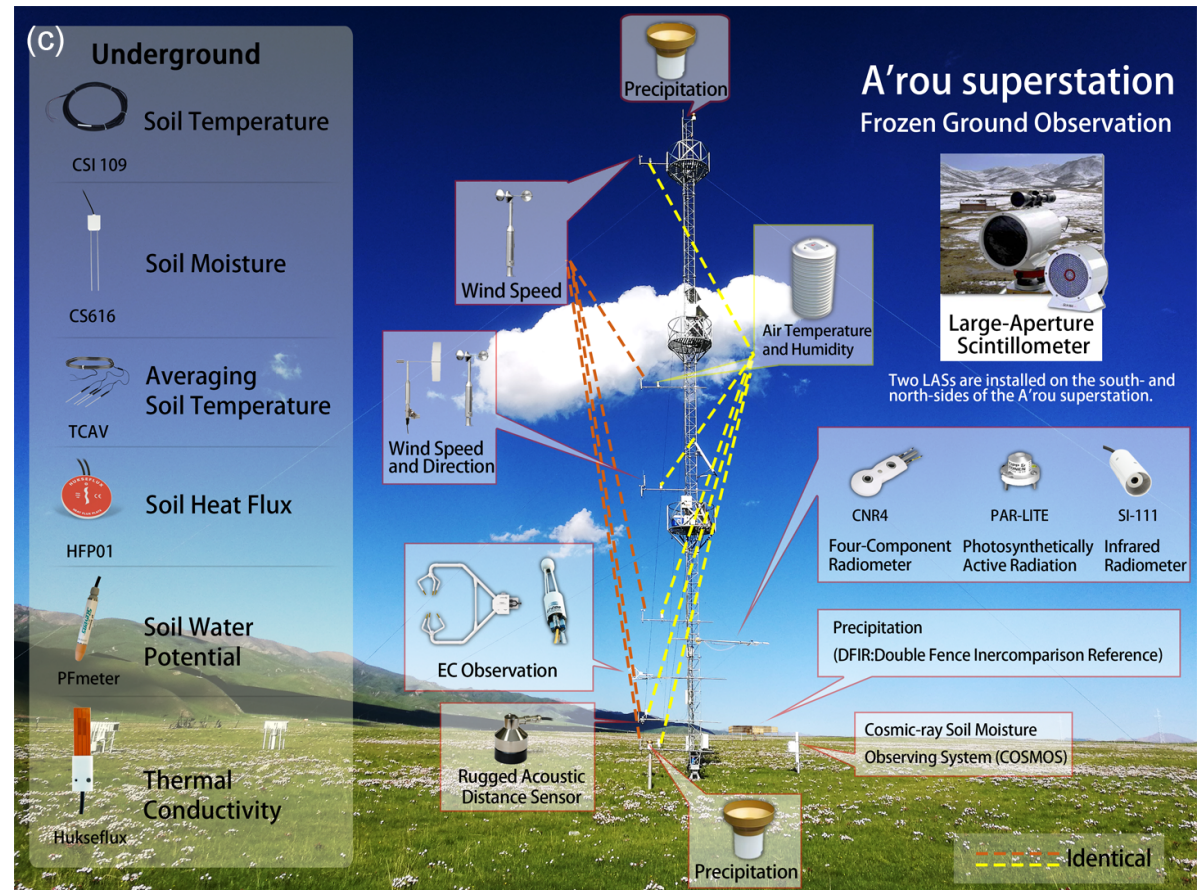

Figure 2. Experimental design: (a) hydrometeorological observation, (b) snow observation and (c) frozen-ground observation.

Table 1. List of seven AMSs and two superstations with detailed information.

\begin{tabular}{lllrrlll}
\hline ID & Name & Longitude & Latitude & Elevation $(\mathrm{m})$ & Legend & Land cover & Observation period \\
\hline 1 & A'rou frozen-ground superstation $^{\mathrm{a}, \mathrm{b}}$ & $100.46^{\circ} \mathrm{E}$ & $38.05^{\circ} \mathrm{N}$ & 3033 & $\mathrm{M}, \mathrm{F}, \mathrm{E}$ & Alpine grassland & From October 2012 \\
2 & Yakou snow superstation $^{\mathrm{a}}$ & $100.24^{\circ} \mathrm{E}$ & $38.01^{\circ} \mathrm{N}$ & 4145 & $\mathrm{M}, \mathrm{S}, \mathrm{E}$ & Tundra & From January 2014 \\
3 & Jingyangling station $_{4}$ & $101.12^{\circ} \mathrm{E}$ & $37.84^{\circ} \mathrm{N}$ & 3750 & $\mathrm{M}$ & Alpine meadow & From August 2013 \\
4 & E'bao station $_{5}$ & $100.92^{\circ} \mathrm{E}$ & $37.95^{\circ} \mathrm{N}$ & 3294 & $\mathrm{M}$ & Alpine grassland & June 2013-September 2016 \\
6 & Huangcaogou station $^{\prime}$ 'rou north-facing station & $100.73^{\circ} \mathrm{E}$ & $38.00^{\circ} \mathrm{N}$ & 3137 & $\mathrm{M}$ & Alpine grassland & June 2013-April 2015 \\
7 & A'rou south-facing station $_{8}$ & $100.41^{\circ} \mathrm{E}$ & $37.98^{\circ} \mathrm{N}$ & 3536 & $\mathrm{M}$ & Alpine grassland & August 2013-December 2014 \\
8 & Huangzangsi station $_{9}$ & $100.52^{\circ} \mathrm{E}$ & $38.09^{\circ} \mathrm{N}$ & 3529 & $\mathrm{M}$ & Alpine grassland & August 2013-September 2015 \\
& Dashalong station $^{\mathrm{a}}$ & $100.19^{\circ} \mathrm{E}$ & $38.23^{\circ} \mathrm{N}$ & 2612 & $\mathrm{M}$ & Farmland & June 2013-April 2015 \\
\hline
\end{tabular}

Note: ${ }^{a}$ Indicates that the flux was observed by eddy covariance (EC). ${ }^{\mathrm{b}}$ Indicates that the flux was observed by LAS. Legend: M, F, S and E represent the hydrometeorological, frozen-ground, snow cover and evapotranspiration observations, respectively.

\subsubsection{Radiation}

Radiation data were collected every 30 min during various periods by four-component radiometers installed at all the AMSs (at a height of $6 \mathrm{~m}$ at seven standard AMSs and at a height of $1 \mathrm{~m}$ at the Yakou snow superstation), which include downward shortwave radiation (DSR, solar radiation), upward shortwave radiation (USR), downward longwave radiation (DLR), upward longwave radiation (ULR) and net radiation $(\mathrm{Rn})$. In general, the DSR, DLR, ULR and Rn data were consistent among sites and throughout the years but varied with seasonal changes. However, the USR data exhibited significant differences among sites, specifically at the A'rou south-facing slope station and the Yakou snow superstation. At the Yakou snow superstation, the USR data were noticeably higher than the other stations due to the high albedo of snow cover. In contrast, minimum USR was found at the south-facing slope possibly due to sufficient sunshine and little snow cover distributed in the area. At the A'rou frozen-ground superstation, to observe vegetation in a typical alpine ecosystem, photosynthetically active radiation (PAR) was also monitored at an interval of $30 \mathrm{~min}$ during the observation period.

\subsubsection{Wind speed and direction}

Wind speed and direction were monitored $10 \mathrm{~m}$ above the ground at an interval of $30 \mathrm{~min}$ during various periods. Specifically, at the A'rou frozen-ground superstation, wind speed and direction were observed at heights of 1, 2, 5, 15 and $25 \mathrm{~m}$ every $30 \mathrm{~min}$ from 14 October 2012 to 31 Decem- 
Table 2. Measuring variables, sensors and locations.

\begin{tabular}{|c|c|c|c|c|c|c|}
\hline Variables & Sensors & Range & Accuracy & 7 AMSs & $\begin{array}{l}\text { Yakou snow } \\
\text { superstation }\end{array}$ & $\begin{array}{l}\text { A'rou frozen-ground } \\
\text { superstation }\end{array}$ \\
\hline \multirow[t]{2}{*}{$\begin{array}{l}\text { Air temperature } \\
\left(\mathrm{Ta},{ }^{\circ} \mathrm{C}\right)\end{array}$} & $\begin{array}{l}\text { Vaisala: } \\
\text { HMP45C, } \\
\text { HMP45AC }\end{array}$ & -40 to $+60^{\circ}$ & $\pm 0.2^{\circ} @ 20^{\circ}$ & \multirow[t]{2}{*}{$5 \mathrm{~m}$} & \multirow[t]{2}{*}{$5 \mathrm{~m}$} & \multirow[t]{2}{*}{$1,2,5,10,15$ and $25 \mathrm{~m}$} \\
\hline & $\begin{array}{l}\text { HMP45D, } \\
\text { HMP45AD }\end{array}$ & -40 to $+60^{\circ}$ & $\pm 0.2^{\circ} @ 20^{\circ}$ & & & \\
\hline \multirow[t]{2}{*}{$\begin{array}{l}\text { Air humidity } \\
(\mathrm{RH}, \%)\end{array}$} & $\begin{array}{l}\text { Vaisala: } \\
\text { HMP45C, } \\
\text { HMP45AC }\end{array}$ & 0 to $100 \% \mathrm{RH}$ & $\begin{array}{l}\text { @ } 20^{\circ} \text { : } \\
\pm 2 \% \mathrm{RH}(0 \% \text { to } 90 \%) \\
\pm 3 \% \mathrm{RH}(90 \% \text { to } 100 \%)\end{array}$ & \multirow[t]{2}{*}{$5 \mathrm{~m}$} & \multirow[t]{2}{*}{$5 \mathrm{~m}$} & \multirow[t]{2}{*}{$1,2,5,10,15$ and $25 \mathrm{~m}$} \\
\hline & $\begin{array}{l}\text { HMP45D, } \\
\text { HMP45AD }\end{array}$ & 0.8 to $100 \% \mathrm{RH}$ & $\begin{array}{l}\text { @ } 20^{\circ}: \\
\pm 2 \% \operatorname{RH}(0 \% \text { to } 90 \%) \\
\pm 3 \% \operatorname{RH}(90 \% \text { to } 100 \%)\end{array}$ & & & \\
\hline \multirow{3}{*}{$\begin{array}{l}\text { Wind speed } \\
\left(\mathrm{WS}, \mathrm{m} \mathrm{s}^{-1}\right)\end{array}$} & MetOne: 010C & 0 to $60 \mathrm{~m} \mathrm{~s}^{-1}$ & $\pm 0.07 \mathrm{~m} \mathrm{~s}^{-1}$ & \multirow[t]{3}{*}{$10 \mathrm{~m}$} & \multirow[t]{3}{*}{$10 \mathrm{~m}$} & \multirow[t]{3}{*}{$1,2,5,10,15$ and $25 \mathrm{~m}$} \\
\hline & 034B & 0 to $75 \mathrm{~m} \mathrm{~s}^{-1}$ & $\begin{array}{l} \pm 0.12 \mathrm{~m} \mathrm{~s}^{-1} \text { for } \\
W S<10.1 \mathrm{~m} \mathrm{~s}^{-1} ; \pm 1.1 \% \text { of } \\
\text { reading for } \mathrm{WS}>10.1 \mathrm{~m} \mathrm{~s}^{-1}\end{array}$ & & & \\
\hline & RM Young: 03001 & 0 to $50 \mathrm{~m} \mathrm{~s}^{-1}$ & $\pm 0.5 \mathrm{~m} \mathrm{~s}^{-1}$ & & & \\
\hline \multirow{3}{*}{$\begin{array}{l}\text { Wind direction } \\
\left(\mathrm{WD},{ }^{\circ}\right)\end{array}$} & MetOne: 020C & 0 to $360^{\circ}$ & $\pm 3^{\circ}$ & \multirow[t]{3}{*}{$10 \mathrm{~m}$} & \multirow[t]{3}{*}{$10 \mathrm{~m}$} & \multirow[t]{3}{*}{$2 \mathrm{~m}$} \\
\hline & 034B & 0 to $360^{\circ}$ & $\pm 4^{\circ}$ & & & \\
\hline & RM Young: 03001 & 0 to $360^{\circ}$ & $\pm 5^{\circ}$ & & & \\
\hline \multirow[t]{2}{*}{$\begin{array}{l}\text { Four-component radia- } \\
\text { tion (DR/UR/DLR_Cor/ } \\
\text { ULR_Cor, } \mathrm{W} \mathrm{m}^{-2} \text { ) }\end{array}$} & $\begin{array}{l}\text { Kipp \& Zonen: } \\
\text { CNR1 }\end{array}$ & $\begin{array}{l}\text { Pyranometer: } \\
0 \text { to } 2000 \mathrm{~W} \mathrm{~m}^{-2} \\
\text { Pyrgeometer: } \\
-250 \quad \text { to } \\
250 \mathrm{~W} \mathrm{~m}^{-2}\end{array}$ & $\begin{array}{l}\text { Uncertainty in daily total } \\
\text { Pyranometer: } \pm 10 \% \\
\text { Pyrgeometer: } \pm 10 \%\end{array}$ & \multirow[t]{2}{*}{$6 \mathrm{~m}$} & \multirow[t]{2}{*}{$6 \mathrm{~m}$} & \multirow[t]{2}{*}{$5 \mathrm{~m}$} \\
\hline & $\begin{array}{l}\text { Kipp \& Zonen: } \\
\text { CNR4 }\end{array}$ & $\begin{array}{l}\text { Pyranometer: } \\
0 \text { to } 2000 \mathrm{~W} \mathrm{~m}^{-2} \\
\text { Pyrgeometer: } \\
-250 \quad \text { to } \\
250 \mathrm{~W} \mathrm{~m}^{-2}\end{array}$ & $\begin{array}{l}\text { Uncertainty in daily total: } \\
\text { Pyranometer: }<5 \% \\
\text { Pyrgeometer: }<10 \%\end{array}$ & & & \\
\hline \multirow{2}{*}{$\begin{array}{l}\text { Photosynthetically active } \\
\text { radiation } \\
\left(\mathrm{PAR}, \mu \mathrm{mol} \mathrm{m}{ }^{-2} \mathrm{~s}^{-1}\right)\end{array}$} & $\begin{array}{l}\text { Kipp \& Zonen: } \\
\text { PQS-1 }\end{array}$ & $\begin{array}{l}0 \text { to } 10000 \\
\mu \mathrm{mol} \mathrm{m}\end{array}$ & 4 to $10 \mu v$ per $\mu \mathrm{mol} \mathrm{m}^{-2} \mathrm{~s}^{-1}$ & & & \multirow[t]{2}{*}{$6 \mathrm{~m}$} \\
\hline & PAR-LITE & $\begin{array}{l}0 \quad \text { to } \\
10000 \mu \mathrm{mol} \mathrm{m}^{-2} \mathrm{~s}^{-1}\end{array}$ & 4 to $6 \mu v$ per $\mu \mathrm{mol} \mathrm{m}^{-2} \mathrm{~s}^{-1}$ & & & \\
\hline \multirow[t]{2}{*}{$\begin{array}{l}\text { Infrared } \\
\left(\mathrm{IRT},{ }^{\circ} \mathrm{C}\right)\end{array}$} & Apogee: SI-111 & -40 to $70^{\circ}$ & $\begin{array}{l} \pm 0.2^{\circ} @-10 \text { to }+65^{\circ} \\
\pm 0.5^{\circ} @-40 \text { to }+70^{\circ}\end{array}$ & \multirow[t]{2}{*}{$\begin{array}{l}6 \mathrm{~m} \\
(2 \text { repeats })\end{array}$} & \multirow[t]{2}{*}{$\begin{array}{l}6 \mathrm{~m} \\
(2 \text { repeats })\end{array}$} & \multirow[t]{2}{*}{$\begin{array}{l}5 \mathrm{~m} \\
(2 \text { repeats })\end{array}$} \\
\hline & Avalon: IRTC3 & -20 to $60^{\circ}$ & $\pm 0.3^{\circ}$ & & & \\
\hline \multirow[t]{2}{*}{$\begin{array}{l}\text { Precipitation } \\
\text { (Rain, mm) }\end{array}$} & $\begin{array}{l}\text { Texas Electronics: } \\
\text { TE525M }\end{array}$ & 0 to $+50^{\circ}$ & $\begin{array}{l}\text { Up to } 10 \mathrm{~mm} \mathrm{~h}^{-1}: \pm 1 \% \\
10 \text { to } 20 \mathrm{~mm} \mathrm{~h}^{-1}:+0,-3 \% \\
20 \text { to } 30 \mathrm{~mm} \mathrm{~h}^{-1}:+0,-5 \%\end{array}$ & \multirow[t]{2}{*}{$10 \mathrm{~m}$} & \multirow[t]{2}{*}{$\begin{array}{l}3 \mathrm{~m} \\
10 \mathrm{~m}\end{array}$} & \multirow[t]{2}{*}{$5 \mathrm{~m}$ (DFIR) } \\
\hline & Geonor: T200BM3 & -40 to $60^{\circ}$ & $0.1 \% \mathrm{FS}$ & & & \\
\hline \multirow{2}{*}{$\begin{array}{l}\text { Air pressure } \\
(P, \text { hpa })\end{array}$} & Setra: CS100 & $600-1100 \mathrm{hPa}$ & $\pm 0.5 \mathrm{hPa}$ at $+20^{\circ} \mathrm{C}$ & \multirow[t]{2}{*}{$0.5 \mathrm{~m}$} & \multirow[t]{2}{*}{$0.5 \mathrm{~m}$} & \multirow[t]{2}{*}{$2 \mathrm{~m}$} \\
\hline & Vaisala: PTB110 & $500-1100 \mathrm{hPa}$ & $\pm 0.3 \mathrm{hPa}$ at $+20^{\circ} \mathrm{C}$ & & & \\
\hline $\begin{array}{l}\text { Eddy covariance } \\
\text { (EC) }\end{array}$ & $\begin{array}{l}\text { Campbell Scientific } \\
\text { instrument }(\mathrm{CSI}) \text {, } \\
\text { LI-COR: CSAT3 and } \\
\text { Li7500A } \\
\text { CSAT3 and Li7500 }\end{array}$ & $\begin{array}{l}\mathrm{CO}_{2}: \quad 0- \\
3000 \text { ppm } \\
\mathrm{H}_{2} \mathrm{O}: 0-60 \mathrm{ppt}\end{array}$ & $\begin{array}{l}\mathrm{CO}_{2}: \text { within } 1 \% \text { of reading } \\
\mathrm{H}_{2} \mathrm{O} \text { : within } 2 \% \text { of reading }\end{array}$ & $\begin{array}{l}4.5 \mathrm{~m} \text { (Dasha- } \\
\text { long only) }\end{array}$ & $3 \mathrm{~m}$ & $3.5 \mathrm{~m}$ \\
\hline $\begin{array}{l}\text { Large aperture scintil- } \\
\text { lometer } \\
\text { (LAS) }\end{array}$ & $\begin{array}{l}\text { SCINTEC: BLS450; } \\
\text { Rainroot: ZZLAS }\end{array}$ & $250 \mathrm{~m}-6 \mathrm{~km}$ & & & & $9.5 \mathrm{~m}$ \\
\hline
\end{tabular}


Table 2. Continued.

\begin{tabular}{|c|c|c|c|c|c|c|}
\hline Variables & Sensors & Range & Accuracy & 7 AMSs & $\begin{array}{l}\text { Yakou snow } \\
\text { superstation }\end{array}$ & $\begin{array}{l}\text { A'rou frozen-ground } \\
\text { superstation }\end{array}$ \\
\hline \multirow{4}{*}{$\begin{array}{l}\text { Soil heat flux } \\
\left(G_{\mathrm{S}}, \mathrm{W} \mathrm{m}^{-2}\right)\end{array}$} & Hukseflux: & $\pm 2000 \mathrm{~W} \mathrm{~m}^{-2}$ & \pm 3 of reading & \multirow{4}{*}{$\begin{array}{l}6 \mathrm{~cm} \\
\text { below ground } \\
(3 \text { repeats) }\end{array}$} & \multirow{4}{*}{$\begin{array}{l}6 \mathrm{~cm} \\
\text { below ground } \\
(3 \text { repeats })\end{array}$} & \multirow{4}{*}{$\begin{array}{l}6 \mathrm{~cm} \\
\text { below ground } \\
(3 \text { repeats })\end{array}$} \\
\hline & HFP01SC & & & & & \\
\hline & HFP01 & $\pm 2000 \mathrm{~W} \mathrm{~m}^{-2}$ & $\begin{array}{l}\text { within }-15 \% \text { to }+5 \% \text { in } 12 \mathrm{~h} \\
\text { totals }\end{array}$ & & & \\
\hline & Avalon: HFT3 & $\pm 100 \mathrm{~W} \mathrm{~m}^{-2}$ & $< \pm 5$ of reading & & & \\
\hline $\begin{array}{l}\text { Average soil temper- } \\
\text { ature } \\
\left(\mathrm{TCAV},{ }^{\circ} \mathrm{C}\right)\end{array}$ & Avalon: TCAV & -55 to $+85^{\circ}$ & $\pm 0.3^{\circ}$ & & & 2 and $4 \mathrm{~cm}$ \\
\hline \multirow[t]{2}{*}{$\begin{array}{l}\text { Soil temperature pro- } \\
\text { file }\left(T_{\mathrm{s}},{ }^{\circ} \mathrm{C}\right)\end{array}$} & CSI: $109,109 \mathrm{ss}$ & -40 to $+70^{\circ}$ & $\begin{array}{l}-40^{\circ} \mathrm{C}: \pm 0.6^{\circ} \mathrm{C} \text { tolerance } \\
0{ }^{\circ} \mathrm{C}: \pm 0.38^{\circ} \mathrm{C} \text { tolerance } \\
25^{\circ} \mathrm{C}: \pm 0.1^{\circ} \mathrm{C} \text { tolerance } \\
50^{\circ} \mathrm{C}: \pm 0.3^{\circ} \mathrm{C} \text { tolerance } \\
70^{\circ} \mathrm{C}: \pm 0.4^{\circ} \mathrm{C} \text { tolerance }\end{array}$ & \multirow[t]{2}{*}{$\begin{array}{l}0,4,10,20, \\
40,80,120 \text { and } \\
160 \mathrm{~cm} \text { below } \\
\text { ground }\end{array}$} & \multirow[t]{2}{*}{$\begin{array}{l}0,4,10,20 \\
40,80,120 \text { and } \\
160 \mathrm{~cm} \text { below } \\
\text { ground }\end{array}$} & \multirow[t]{2}{*}{$\begin{array}{l}2,4 \text { (3 repeats), } 6,10 \\
(3 \text { repeats), 15, 20,30, } \\
40,60,80,120,160,200, \\
240,280 \text { and } 320 \mathrm{~cm} \text { be- } \\
\text { low ground }\end{array}$} \\
\hline & Avalon: AV-10T & -45 to $+65^{\circ}$ & $\begin{array}{l}< \pm 0.2^{\circ} \text { over } 0 \text { to } 60^{\circ} ; \pm 0.4 @ \\
-35^{\circ}\end{array}$ & & & \\
\hline \multirow[t]{2}{*}{$\begin{array}{l}\text { Soil moisture profile } \\
\left(M_{\mathrm{S}}, \%\right)\end{array}$} & CSI: CS616 & $0 \%$ to $50 \% \mathrm{VWC}$ & $\begin{array}{l} \pm 2.5 \% \text { VWC using standard } \\
\text { calibration with bulk EC of } \leq \\
0.5 \mathrm{dS} \mathrm{m}^{-1} \text {, bulk density of } \leq \\
1.55 \mathrm{~g} \mathrm{~cm}^{-3} \text { ) }\end{array}$ & \multirow[t]{2}{*}{$\begin{array}{l}4,10,20,40, \\
80, \quad 120 \text { and } \\
160 \mathrm{~cm} \text { below } \\
\text { ground }\end{array}$} & \multirow[t]{2}{*}{$\begin{array}{l}4,10,20,40, \\
80, \quad 120 \text { and } \\
160 \mathrm{~cm} \text { below } \\
\text { ground }\end{array}$} & \multirow[t]{2}{*}{$\begin{array}{l}2,4 \text { (3 repeats), } 6,10 \\
(3 \text { repeats), 15, 20, 30, } \\
40,60,80,120,160,200, \\
240,280 \text { and } 320 \mathrm{~cm} \text { be- } \\
\text { low ground }\end{array}$} \\
\hline & Decagon: ECH2O-5 & $\begin{array}{l}0 \% \text { to } 100 \% \\
\text { VWC }\end{array}$ & $\begin{array}{l} \pm 0.03 \mathrm{~m}^{3} \mathrm{~m}^{-3} \text { typical in min- } \\
\text { eral soils that have solution EC } \\
<8 \mathrm{dS} \mathrm{m}^{-1} \text {; } \\
\text { Medium specific calibration: } \\
\pm 0.02 \mathrm{~m}^{3} \mathrm{~m}^{-3} \text { in any porous } \\
\text { medium }( \pm 2 \%)\end{array}$ & & & \\
\hline $\begin{array}{l}\text { Soil water potential } \\
\text { (soil_pf, pF) }\end{array}$ & $\begin{array}{l}\text { GeoPrecision: } \\
\text { pF-meter }\end{array}$ & $\mathrm{pF}: 0-7$ & \pm 0.05 & & & $\begin{array}{l}4,10,20,40,80 \text { and } \\
120 \mathrm{~cm} \text { below ground }\end{array}$ \\
\hline $\begin{array}{l}\text { Soil thermal conduc- } \\
\text { tivity (Soil_TCon, } \\
\mathrm{W} \mathrm{m}^{-1} \mathrm{~K}^{-1} \text { ) }\end{array}$ & Hukseflux: ТР01 & $\begin{array}{l}0.3 \\
5 \mathrm{~W} \mathrm{~m}^{-1} \mathrm{~K}^{-1}\end{array}$ & $\pm 5 \%$ & & & $\begin{array}{l}4,10,20,40,80 \text { and } \\
120 \mathrm{~cm} \text { below ground }\end{array}$ \\
\hline $\begin{array}{l}\text { Snow depth } \\
(\mathrm{mm})\end{array}$ & CSI: SR50A & $0-10 \mathrm{~m}$ & $\pm 1 \mathrm{~cm}$ & & $2.5 \mathrm{~m}$ & $2 \mathrm{~m}$ \\
\hline $\begin{array}{l}\text { Snow water equiva- } \\
\text { lent (SWE, mm) }\end{array}$ & CSI: CS725 & $0-600 \mathrm{~mm}$ & $\begin{array}{l} \pm 15 \mathrm{~mm} \text { (from } 0 \text { to } 300 \mathrm{~mm} \text { ) } \\
\pm 15 \% \text { (from } 300 \text { to } 600 \mathrm{~mm} \text { ) }\end{array}$ & & $2.5 \mathrm{~m}$ & \\
\hline $\begin{array}{l}\text { Drifting snow (snow- } \\
\text { drift, } \mathrm{g} \mathrm{m}^{-2} \mathrm{~s}^{-1} \text { ) }\end{array}$ & IAV: FlowCapt & $0-250 \mathrm{~g} \mathrm{~m}^{-2} \mathrm{~s}^{-1}$ & $1 \mathrm{~g} \mathrm{~m}^{-2} \mathrm{~s}^{-1}$ & & $\begin{array}{l}0-1, \quad 1-2 \text { and } \\
2-3 \mathrm{~m}\end{array}$ & \\
\hline
\end{tabular}

DFIR represents a T200BM3 with double fence intercomparison reference. The DFIRs were established in October 2016 at the Yakou snow superstation and in August 2017 at the A'rou frozen-ground superstation.

ber 2017. Consistent data for both variables were noticed at all heights with variations among sites.

\subsubsection{Precipitation and evapotranspiration (ET)}

Among all the long-term monitored meteorological variables, precipitation and ET data at the Yakou, A'rou and Dashalong stations were collected and displayed in Fig. 3. Precipitation data were measured by rain gauges, while ET rates were measured using the EC at the Dashalong, Yakou and A'rou stations (Table 2). In particular, only the precipitation gauge (T200B, Geonor, USA) at the Yakou snow superstation was sheltered with DFIRs to collect both solid and liquid precipitation data. Because the uncertainties of the precipitation gauge (T200B) may result from the unsta- ble voltage or unknown abnormity, evaporation of the liquid surface, and offset of the instrument, the post-processing included three steps: (1) manual calibration by adding a certain amount of water into the gauge, (2) abnormal data rejection using the forward-backward filtering (Gustafsson, 1996) and (3) hourly precipitation calculation (using accumulated data before and after each hour). At the other stations, precipitation gauges (TE525M, Texas Electronics, USA) were neither sheltered by Alter shields nor DFIRs. Therefore, only liquid precipitation data were collected. Precipitation data were provided in raw format without any post-processing, which might be underestimated because of the wind and snowfall.

On the other hand, the instruments of EC were calibrated every 6 months, and the raw data acquired at $10 \mathrm{~Hz}$ were processed using the EdiRe software (Uni- 

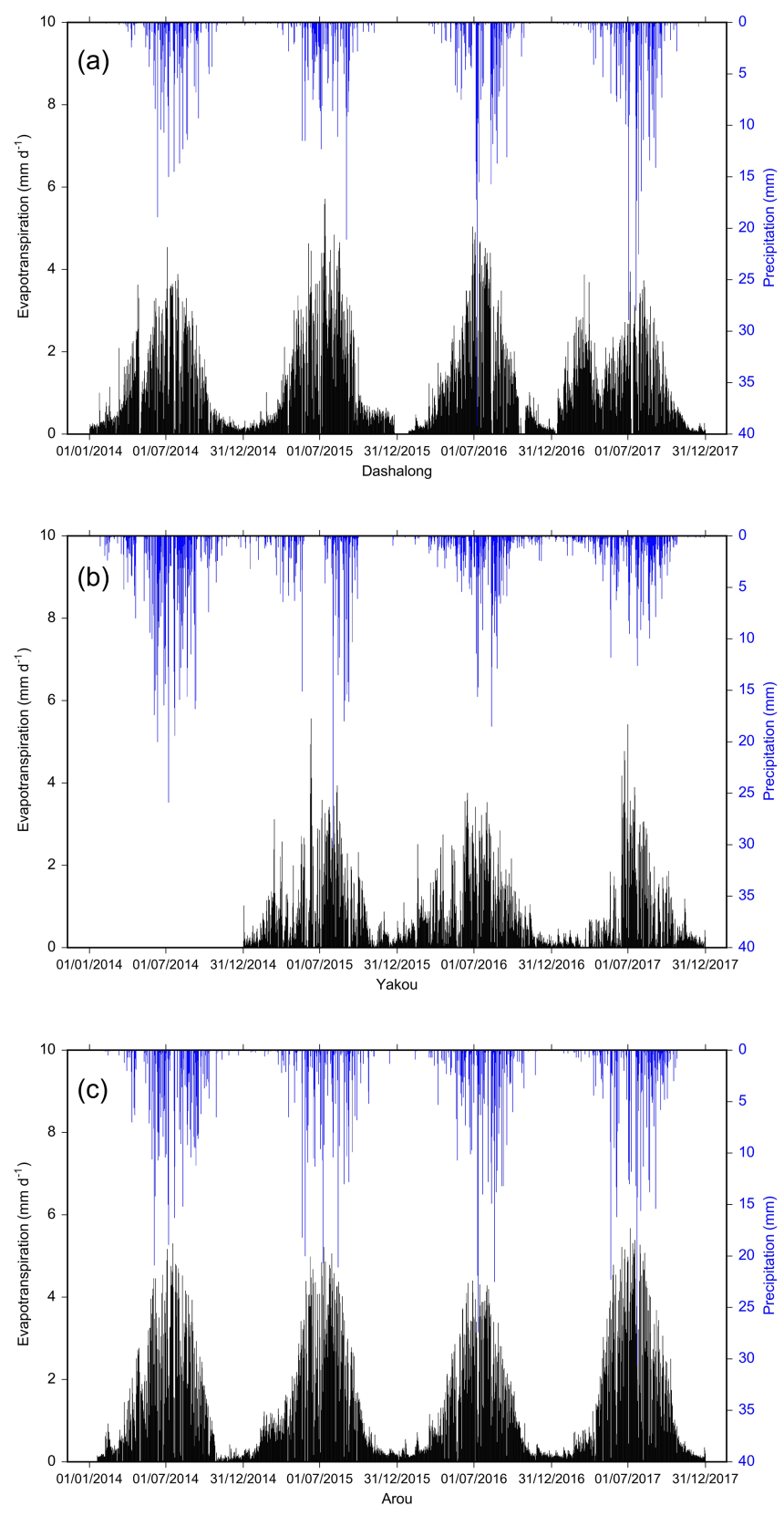

Figure 3. Daily precipitation and ET data at the (a) Dashalong, (b) Yakou and (c) A'rou stations from 2014 to 2017.

versity of Edinburgh, https://www.geos.ed.ac.uk/homes/jbm/ micromet/EdiRe/, last access: 5 September 2019), including spike detection and removal, lag correction of $\mathrm{H}_{2} \mathrm{O} / \mathrm{CO}_{2}$ relative to the vertical wind component, sonic virtual temperature correction, coordinate rotation (2-D rotation), corrections for density fluctuation (Webb-Pearman-Leuning correction) and frequency response correction (Liu et al., 2011). EC data were subsequently averaged at an interval of $30 \mathrm{~min}$ and divided into three classes according to the quality assessment method of stationarity $(\Delta \mathrm{st})$ and the integral tur- bulent characteristics test (ITC), as proposed by Foken and Wichura (1996): class 1 (level $0: \Delta$ st $<30$ and ITC $<30$ ), class 2 (level 1: $\Delta$ st $<100$ and $\mathrm{ITC}<100$ ) and class 3 (level 2: $\Delta$ st $>100$ and ITC $>100$ ), which represent high-, medium- and low-quality data, respectively. In addition to the above processing steps, half-hourly flux data were screened using a four-step procedure: (1) data from periods of sensor malfunction were rejected, (2) data collected before or after $1 \mathrm{~h}$ of precipitation were rejected, (3) incomplete $30 \mathrm{~min}$ data were rejected when the missing data constituted more than $3 \%$ of the $30 \mathrm{~min}$ raw record and (4) data were rejected at night when the friction velocity $\left(u^{*}\right)$ was less than $0.1 \mathrm{~m} \mathrm{~s}^{-1}$ (Blanken et al., 1998). There were 48 records per day, with gaps denoted by -6999 .

The annual precipitation was approximately 570 and $420 \mathrm{~mm}$ at the A'rou frozen-ground superstation and Dashalong station, respectively, while it reached $600-800 \mathrm{~mm}$ at the Yakou snow superstation. It is interesting to observe that unlike the other two stations, at the Yakou snow superstation, a remarkable amount of ET was found not only in summer but also in spring and fall due to excessive ET on the surface of the snow cover. Also shown in Fig. 3, similar patterns were clearly observed between precipitation and ET with possible correlations that could be investigated further through hydrological modeling and data analysis.

\subsection{Snow data}

A comprehensive snow dataset from the Yakou snow superstation has been updated since the summer of 2013. The observed snow variables included snow depth, snow water equivalent (SWE) and blowing (drifting) snow. Data obtained from 1 January 2014 to 31 December 2017 are summarized in Fig. 4, with additional plots for precipitation, ET, soil temperature and moisture. Precipitation and ET (Fig. 4a) were explained in Sect. 3.2.4, while soil temperature (measured at six depths below the ground) and moisture (measured at three depths below the ground) under freeze-thaw cycles are presented in Fig. 4e-f as they relate to precipitation and ET. More data with further analysis of frozenground observations at the study site will be introduced in the next section. Snow density and the liquid water contents of the snowpack were also measured by a Snow Pack Analyzer (SPA, Sommer, Austria). Unfortunately, this did not work well, due to the influence of strong wind. Therefore, snow density data, which can be calculated using snow depth and SWE data, are not available at present.

\subsubsection{Snow depth}

Snow depth was measured by SR50A (Campbell Scientific, USA), which determines the distance between the sensor and the target by sending out ultrasonic pulses and listening for the returning echoes reflected from the target. The original snow depth data were available from 1 January 2014 to 

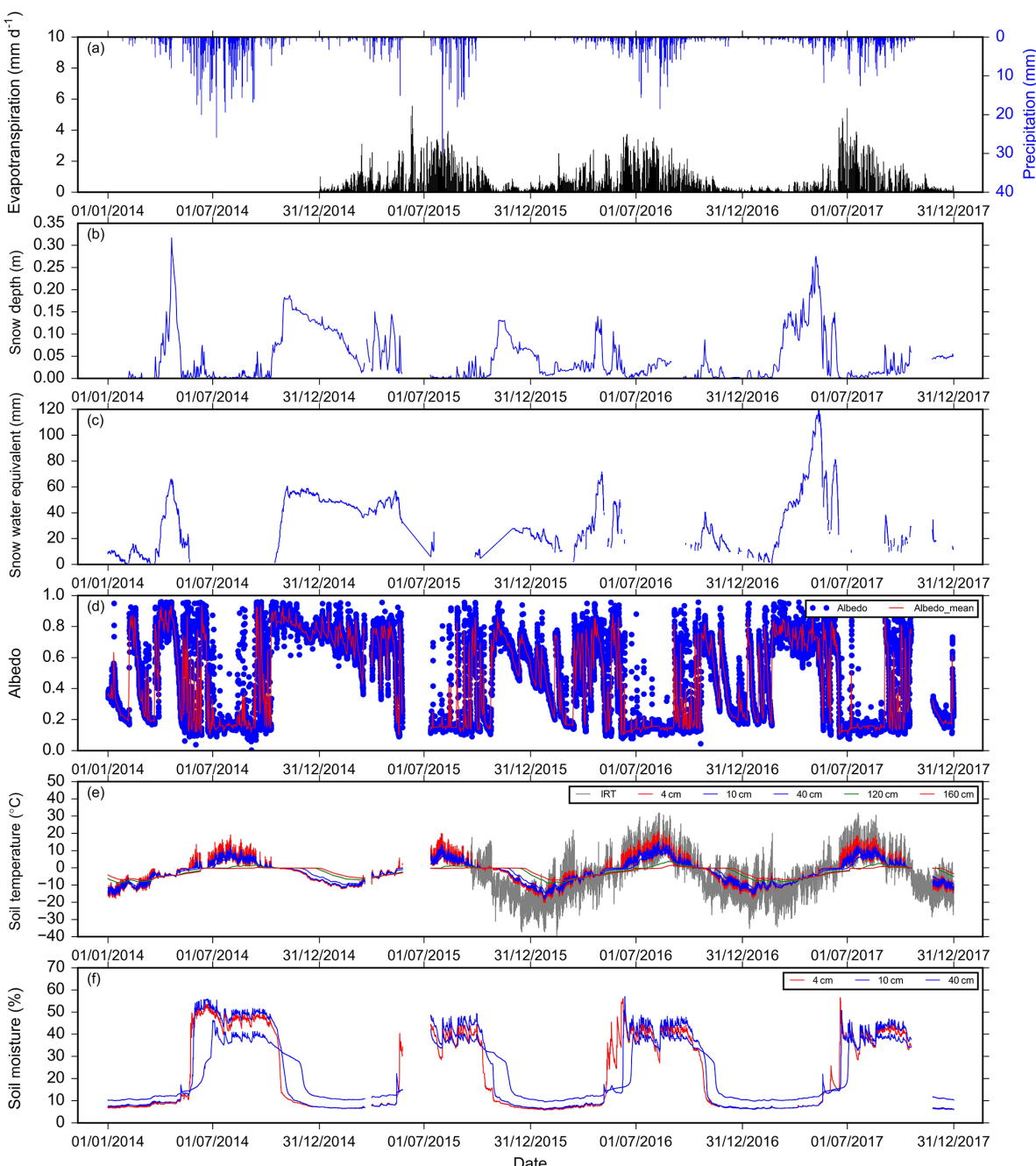

Figure 4. Observations at the Yakou snow superstation from 1 January 2014 to 31 December 2017, including (a) precipitation and ET, (b) snow depth, (c) SWE, (d) albedo, (e) soil temperature and (f) soil moisture.

31 December 2017 (with $53 \mathrm{~d}$ missing due to power loss or instrument malfunction, marked with -6999 in the dataset) at an interval of $30 \mathrm{~min}$. In post-processing, ambient air temperature measured using a WXT520 (Vaisala, USA) was used to calibrate the snow depth data (Webb, 2008). Data were cross-compared with the measured SWE (introduced in the next subsection), suspicious values were deleted manually followed by noise filtering and, finally, data were averaged to daily output. As shown in Fig. 4b, the snow depth has two peaks, in autumn and spring. From 2014 to 2017, the maximum snow depth mostly decreased $(31,16,15$ and $28 \mathrm{~cm}$, respectively), showing an apparent alteration annually. The largest snow depth was found in April, which indicates that in this region, spring snowfall is the dominant and most unique feature in the hydrologic cycle. The measured snow depth data fluctuated in a chaotic pattern due to the strong solar radiation and blowing snow locally, as well as the dry winter, which is typical at the study site.

\subsubsection{Snow water equivalent (SWE)}

Snow water equivalent (SWE) was measured by GMON (CS725 GammaMONitor, Campbell Scientific, USA) from 1 January 2014 to 31 December 2017 at a temporal resolution of $6 \mathrm{~h}$. GMON provides the SWE data by measuring the absorption of natural ground gamma radiation through the snow layer, which depends on the mass of water between the source (the ground) and the radiation detector. The measurement area of the GMON was $50-100 \mathrm{~m}^{2}$. By tracking the number of hits recorded on a daily basis from potassium $(40 \mathrm{~K})$ and thallium (208Tl) energy windows located at 1.46 and $2.61 \mathrm{MeV}$, superior performance was achieved compared with the traditional snow pillow measurement. Specifically, SWE data from GMON were calibrated by snow depth and density manually measured using a snow ruler and shovel twice a day (in the mornings and afternoons) in the spring of 2014. To avoid random uncertainties during calibration, 
a $100 \mathrm{~m} \times 100 \mathrm{~m}$ grid around the GMON was designed to measure snow depth at an interval of $10 \mathrm{~m}$ (100 measuring spots in the grid). Snow density was also manually measured within the grid at six selected locations. The averaged snow depth and density were used to fit the coefficients required by the GMON. With the daily collected SWE data (Fig. 4c), the on-site snow season was defined as being from October to May (of the next year) each year at the Yakou snow superstation, with a maximum value of approximately $120 \mathrm{~mm}$. The daily snow depth and SWE data in the observation period exhibited similar patterns and are thus closely correlated, as seen when comparing Fig. $4 \mathrm{~b}$ and c.

\subsubsection{Snow albedo}

Snow albedo was measured using four-component radiometers described in Sect. 3.1.2 and calculated from the ratio between upward and downward radiations at short waves and long waves. As shown in Fig. 4d, a useful measure of the effective albedo of the snowpack has been provided, which can be reasonably cross-compared with the snow depth and SWE (Fig. 4b-c). It should be noted that the four-component radiation data (provided in raw format) and the albedo data shown in Fig. 4d were calculated by the downward and upward shortwave radiation from 10:00 to 17:30 (local time) in order to filter out values at high solar zenith angles in early mornings and evenings.

\subsubsection{Blowing (drifting) snow}

Blowing (drifting) snow is commonly observed in the Qilian mountains due to its high altitude and complex terrain. It is important to estimate the occurrence of blowing snow because it may cause redistribution of the snow cover and influence the sublimation of snow (G. Li et al., 2018). FlowCapt (IAV, Switzerland) was used to measure the number of blowing snow grains at three heights $(0-1,1-2$ and 2-3 m) every $10 \mathrm{~min}$. The FlowCapt sensor is based on vibro-acoustics, which can provide good qualitative and quantitative information about drifted snow intensity and duration of snowdrift periods. The blowing snow data were available from 1 January 2014 to 20 September 2016 without any gaps. To filter the wind noise during the observation (especially in summer), it was necessary to manually delete the suspicious data by comparing the results with the SWE and snow depth data. The data would be rejected when (1) snow depth was zero, (2) wind speed was less than $3 \mathrm{~m} \mathrm{~s}^{-1}$ or (3) air temperature was higher than $10^{\circ}$. The data collected in 2014 are plotted in Fig. 5, which show that the blowing snow fluxes reached a maximum close to the land surface and decreased with height. Two extreme events were found in May and September during that year.
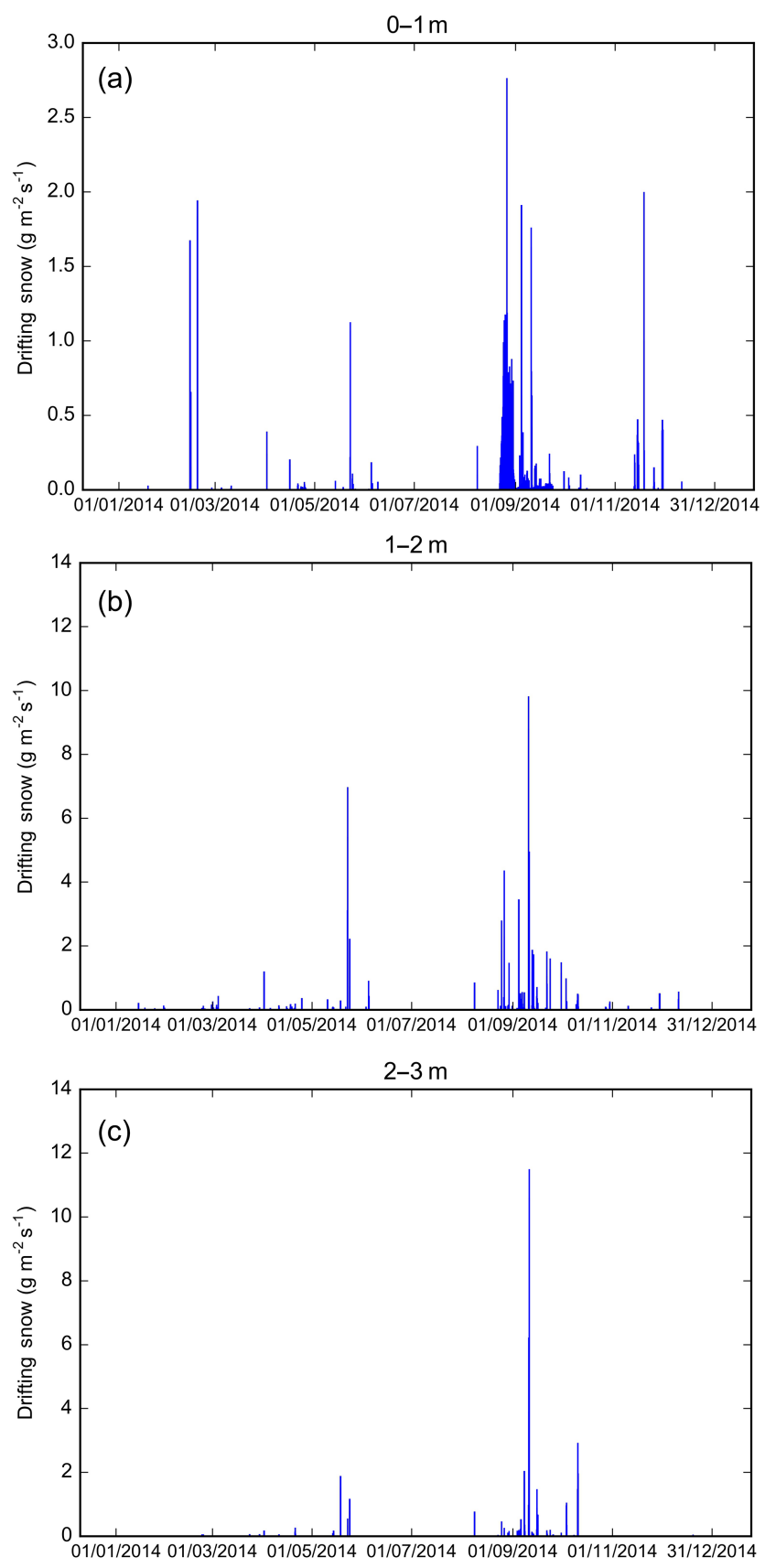

Figure 5. Blowing snow measurement at the Yakou snow superstation from 1 January to 31 December 2014: (a) at the height of 0-1 m, (b) at the height of 1-2 $\mathrm{m}$ and (c) at the height of 2-3 m.

\subsection{Frozen-ground data}

To observe the FTCs of the frozen ground, soil moisture and temperature were measured at all the stations below ground (Table 2). At seven standard AMSs and the Yakou snow superstation, soil temperature was observed at eight depths ( 0 , $4,10,20,40,80,120,160 \mathrm{~cm}$ ), while soil moisture was observed at seven depths $(4,10,20,40,80,120,160 \mathrm{~cm})$. In addition, intensive measurements of both variables in 18 
(a)

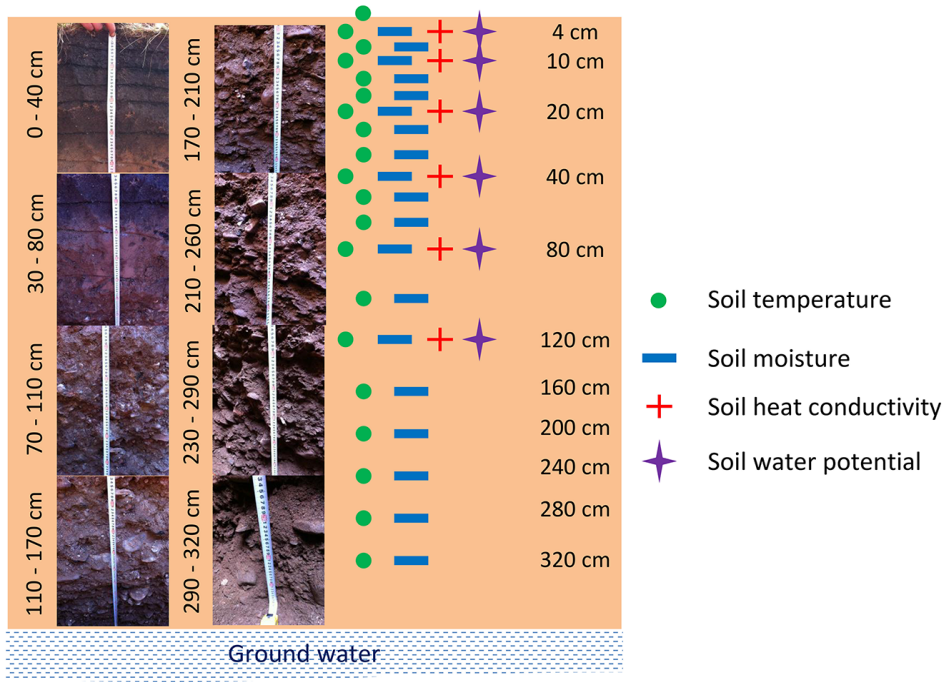

(b)

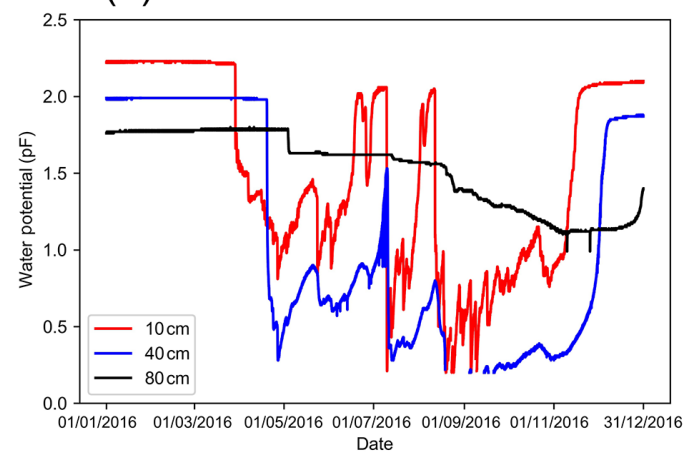

(d)

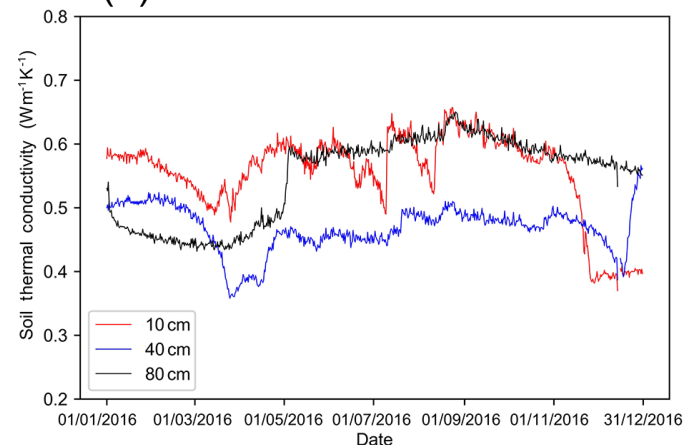

(c)

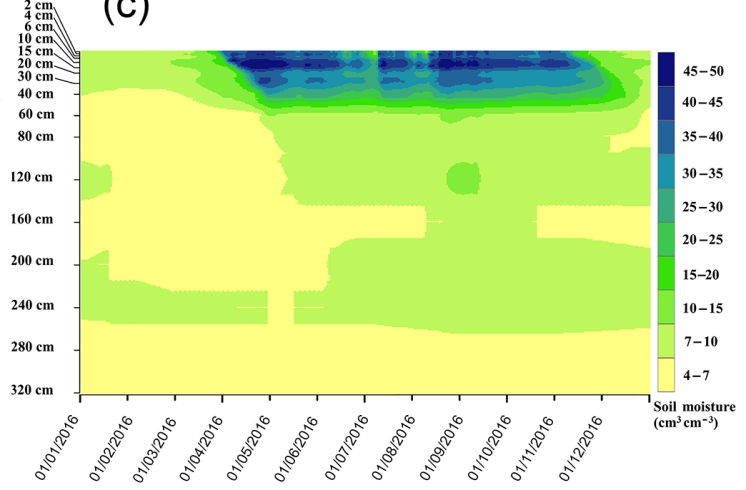

(e)

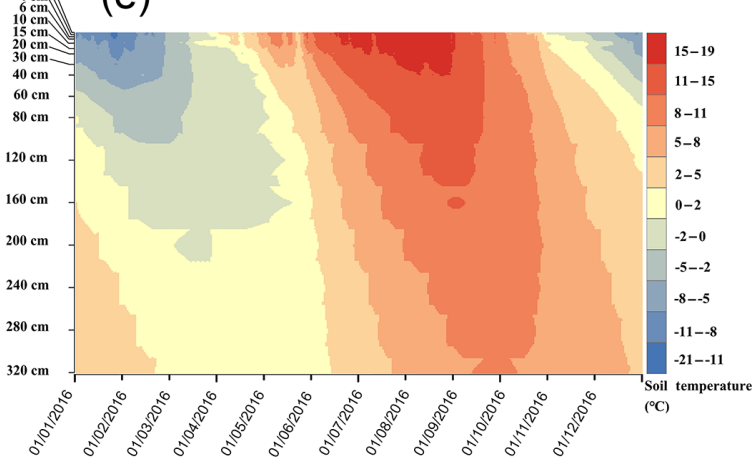

Figure 6. Frozen-ground observation at the A'rou superstation in 2016: (a) soil heterogeneity and layout of the measurements, (b) soil water potential, (c) soil moisture, (d) soil heat conductivity, and (e) soil temperature.

nested layers within $3.2 \mathrm{~m}$ below ground were performed at the A'rou frozen-ground superstation (Table 2, Fig. 6a) to capture the water and energy exchange within the soil. In addition, soil water potential and soil thermal conductivity were measured in the top six layers at an interval of $30 \mathrm{~min}$ (Table 2, Fig. 6a). The datasets are available from 5 December 2012 to 31 December 2017, with intermittent loss mostly due to power loss and sensor malfunctions at high altitudes. The frozen-ground data were provided in raw format without any post-processing. Soil water potential and moisture data are presented in Fig. $6 \mathrm{~b}-\mathrm{c}$, showing consistent trends in topsoil layers if cross-compared because the soil water potential represents the capacity for storage of moisture within the soil. Figure $6 \mathrm{~b}-\mathrm{c}$ also show that, during the melting season, 
relatively low soil moisture data were recorded due to the frozen status of the soil, while a sharp increase and fluctuations of the moisture data were noticed until spring in most of the layers. It was also found that soil moisture was quite low without clear seasonal variations in deeper soil layers $(>60 \mathrm{~cm}$ ), which may be because it is difficult for time domain reflectometry (TDR) sensors to work in bedrock. Figure $6 \mathrm{~d}$ plots the soil heat conductivity in selected layers (10, 40 and $80 \mathrm{~cm}$ ). Soil heat conductivity is difficult to analyze because it is a function of soil density, soil moisture content (ice content in frozen ground) and soil temperature, which cannot be easily calculated using a simple formula. Therefore, site observations can be utilized to evaluate the parameterization of alpine hydrologic models. The soil temperature changes within different layers under the FTCs, including the spatial and temporal variations, are clearly shown in Fig. 6e. Correlated patterns were found between soil moisture and temperature profiles when comparing Fig. $6 \mathrm{c}$ and e, variations of which become more significant close to the land surface. In addition, at the Yakou snow superstation, the soil at $160 \mathrm{~cm}$ below ground was mostly frozen before 2016, with a significant increase to $0^{\circ} \mathrm{C}$ after 2016 , which indicates that the active layer thickness has since increased.

\section{Data availability}

All datasets presented in this paper have been released and are available for free download from the Cold and Arid Regions Science Data Center at Lanzhou (https://doi.org/10.3972/hiwater.001.2019.db, Li, 2019). A specific directory was designated for each observation station with data classified into three categories: hydrometeorological data, snow cover data and frozen-ground data. Short descriptions were also provided for each dataset. Auxiliary data include site descriptions, e.g., a watershed digital elevation model (DEM), shapefiles of the watershed boundary and the station locations.

\section{Conclusions}

In this paper, a suite of alpine hydrology datasets observed from an integrated, distributed and multiscale hydrometeorological, snow and frozen-ground data observation network in the upper reaches of the Heihe River Basin (HRB) is presented. With recent observational advances and decades of effort, the integrated network has served as a test bed for alpine hydrology, cryospheric and meteorological sciences. The associated open-access datasets include high-quality hydrometeorological data with a focus on snow and frozenground observations at the sub-basin and basin scales, which aims to address a variety of scientific questions including, but not limited to, (1) how to provide accurate and effective forcing data for alpine hydrological models; (2) how to integrate observation, simulation, and the acquired datasets for informative understanding; and (3) how perturbations (climate change and human activities) alter hydrologic processes. Our continuous efforts based on the current observation network are three-fold: (1) connecting "below-to-above" ground observations (e.g., incorporating other datasets from airborne and geophysical measurements) and looking into a more systematic investigation of the watershed behavior in an unprecedented manner; (2) developing robust data management assimilation tools and, ultimately with the aid of high-performance computing, building a data-driven modeling platform to accelerate new discoveries and insights; and (3) performing outreach and offering rich possibilities for community collaboration, both within and across sites.

Author contributions. TC, XL, SL, HL, RJ, MM and JW designed the observations. TC, HL, ZX, JT, LX, JD and XY cleaned and organized the datasets. ZX, JT, YZ and ZR maintained the observation network. TC, XY and XL drafted the manuscript, and all authors contributed to the paper writing.

Competing interests. The authors declare that they have no conflict of interest.

Special issue statement. This article is part of the special issue "Hydrometeorological data from mountain and alpine research catchments". It is not associated with a conference.

Acknowledgements. We would like to thank all the scientists, engineers, and students who participated in the field campaigns. We thank the two anonymous reviewers for their thorough reviews and insightful comments that improved the paper.

Financial support. This research has been supported by the Strategic Priority Research Program of the Chinese Academy of Sciences (grant nos. XDA19070101 and XDA20100101) and the National Natural Science Foundation of China (grant nos. 41531174 and 41271356).

Review statement. This paper was edited by John Pomeroy and reviewed by two anonymous referees.

\section{References}

Balk, B. and Elder, K.: Combining binary decision tree and geostatistical methods to estimate snow distribution in a mountain watershed, Water Resour. Res., 36, 13-26, https://doi.org/10.1029/1999WR900251, 2000.

Beniston, M., Keller, F., Koffi, B., and Goyette, S.: Estimates of snow accumulation and volume in the Swiss Alps under chang- 
ing climatic conditions, Theor. Appl. Climatol., 76, 125-140, https://doi.org/10.1007/s00704-003-0016-5, 2003.

Blanken, P. D., Black, T. A., Neumann, H. H., Hartog, C. D., Yang, P. C., Nesic, Z., Staebler, R., Chen, W., and Novak, M. D.: Turbulent flux measurements above and below the overstory of a boreal aspen forest, Bound.-Lay. Meteorol., 89, 109-140, https://doi.org/10.1023/A:1001557022310, 1998.

Brown, J., Hinkel, K. M., and Nelson, F. E.: The circumpolar active layer monitoring (CALM) program: Research designs and initial results, Polar Geogr., 24, 166-258, https://doi.org/10.1080/10889370009377698, 2000.

Caine, N.: Modulation of the diurnal streamflow response by the seasonal snowcover of an alpine basin, J. Hydrol., 137, 245-260, https://doi.org/10.1016/0022-1694(92)90059-5, 1992.

Chahine, M. T.: The hydrological cycle and its influence on climate, Nature, 359, 373-380, https://doi.org/10.1038/359373a0, 1992.

Che, T., Dai, L. Y., Wang, J., Zhao, K., and Liu, Q.: Estimation of snow depth and snow water equivalent distribution using airborne microwave radiometry in the Binggou Watershed, the upper reaches of the Heihe River basin, Int. J. Appl. Earth Obs., 17, 23-32, https://doi.org/10.1016/j.jag.2011.10.014, 2012.

Chen, R., Wang, G., Yang, Y., Liu, J., Han, C., Song, Y., Liu, Z., and Kang, E.: Effects of cryospheric change on alpine hydrology: Combining a model with observations in the upper reaches of the Hei River, China, J. Geophys. Res.-Atmos., 123, 3414-3442, https://doi.org/10.1002/2017JD027876, 2018.

Chen, R. S., Song, Y. X., Kang, E. S., Han, C. T., Liu, J. F., Yang, Y., Qing, W. W., and Liu, Z. W.: A Cryosphere-Hydrology Observation System in a Small Alpine Watershed in the Qilian Mountains of China and Its Meteorological Gradient, Arct. Antarct. Alp. Res., 46, 505-523, https://doi.org/10.1657/1938-4246-46.2.505, 2014.

Chen, Y. Y., Yang, K., Tang, W. J., Qin, J., and Zhao, L.: Parameterizing soil organic carbon's impacts on soil porosity and thermal parameters for Eastern Tibet grasslands, Sci. China Earth Sci., 55, 1001-1011, https://doi.org/10.1007/s11430-012-4433$0,2012$.

Clark, M. P., Slater, A. G., Barrett, A. P., Hay, L. E., McCabe, G. J., Rajagopalan, B., and Leaveslye, G. H.: Assimilation of snow covered area information into hydrologic and land-surface models, Adv. Water Resour., 29, 1209-1221, 2006.

Cline, D. W.: Snow surface energy exchanges and snowmelt at a continental, midlatitude Alpine site, Water Resour. Res., 33, 689-701, https://doi.org/10.1029/97WR00026, 1997.

Dai, L., Che, T., Ding, Y., and Hao, X.: Evaluation of snow cover and snow depth on the Qinghai-Tibetan Plateau derived from passive microwave remote sensing, The Cryosphere, 11, 19331948, https://doi.org/10.5194/tc-11-1933-2017, 2017.

DeBeer, C. M. and Pomeroy, J. W.: Modelling snow melt and snowcover depletion in a small alpine cirque, Canadian Rocky Mountains, Hydrol. Process., 23, 2584-2599, https://doi.org/10.1002/hyp.7346, 2009.

Dewalle, D. R. and Rango, A.: Principles of snow hydrology, Cambridge University Press, 2008.

Essery, R., Li, L., and Pomeroy, J.: A distributed model of blowing snow over complex terrain, Hydrol. Process., 13, 2423-2438, https://doi.org/10.1002/(SICI)10991085(199910)13:14/15<2423::AID-HYP853>3.0.CO;2-U, 1999.
Foken, T. and Wichura, B.: Tools for quality assessment of surfacebased flux measurements, Agr. Forest Meteorol., 78, 83-105, https://doi.org/10.1016/0168-1923(95)02248-1, 1996.

Frei, A., Tedesco, M., Lee, S., Foster, J., Hall, D. K., Kelly, R., and Robinson, D. A.: A review of global satellitederived snow products, Adv. Space Res., 50, 1007-1029, https://doi.org/10.1016/j.asr.2011.12.021, 2012.

Gao, B., Yang, D., Qin, Y., Wang, Y., Li, H., Zhang, Y., and Zhang, T.: Change in frozen soils and its effect on regional hydrology, upper Heihe basin, northeastern Qinghai-Tibetan Plateau, The Cryosphere, 12, 657-673, https://doi.org/10.5194/tc-12657-2018, 2018.

Gao, T., Zhang, T., Guo, H., Hu, Y., Shang, J., and Zhang, Y.: Impacts of the active layer on runoff in an upland permafrost basin, northern Tibetan Plateau, PLoS One, 13, e0192591, https://doi.org/10.1371/journal.pone.0192591, 2018.

Gustafsson, F.: Determining the Initial States in ForwardBackward Filtering, IEEE T. Signal Proces., 44, 988-992, https://doi.org/10.1109/78.492552, 1996.

Hall, D. K. and Riggs, G. A.: Accuracy assessment of the MODIS snow products, Hydrol. Process., 21, 1534-1547, https://doi.org/10.1002/hyp.6715, 2007.

Hardy, J. P., Groffman, P. M., Fitzhugh, R. D., Henry, K. S., Welman, A. T., Demers, J. D., Fahey, T. J., Driscoll, C. T., Tierney, G. L., and Nolan, S.: Snow Depth, Soil Frost and Water Dynamics in a Northern Hardwood Forest, Biogeochemistry, 56, 151-174, https://doi.org/10.1023/A:1013036803050, 2001.

He, Z., Zhao, W., Liu, H., and Tang, Z.: Effect of forest on annual water yield in the mountains of an arid inland river basin: a case study in the Pailugou catchment on northwestern China's Qilian Mountains, Hydrol. Process., 26, 613-621, https://doi.org/10.1002/hyp.8162, 2012.

Hrachowitz, M., Savenije, H. H. G., Bloschl, G., McDonnell, J. J., Sivapalan, M., Pomeroy, J. W., Arheimer, B., Blume, T., Clark, M. P., Ehret, U., Fenicia, F., Freer, J. E., Gelfan, A., Gupta, H. V., Hughes, D. A., Hut, R. W., Montanari, A., Pande, S., Tetzlaff, D., Troch, P. A., Uhlenbrook, S., Wagener, T., Winsemius, H. C., Woods, R. A., Zehe, E., and Cudennec, C.: A decade of Predictions in Ungauged Basins (PUB) - a review, Hydrolog. Sci. J., 58, 1198-1255, https://doi.org/10.1080/02626667.2013.803183, 2013.

Jackson, T. J., Cosh, M. H., Bindlish, R., Starks, P. J., Bosch, D. D., Seyfried, M., Goodrich, D. C., Moran, M. S., and Du, J.: Validation of Advanced Microwave Scanning Radiometer Soil Moisture Products, IEEE T. Geosci. Remote, 48, 4256-4272, https://doi.org/10.1109/TGRS.2010.2051035, 2010.

Jin, R., Li, X., Yan, B., Li, X., Luo, W., Ma, M., Guo, J., Kang, J., Zhu, Z., and Zhao, S.: A Nested Ecohydrological Wireless Sensor Network for Capturing the Surface Heterogeneity in the Midstream Areas of the Heihe River Basin, China, IEEE Geosci. Remote, 11, 2015-2019, https://doi.org/10.1109/LGRS.2014.2319085, 2014.

Kinar, N. J. and Pomeroy, J. W.: Measurement of the physical properties of the snowpack, Rev. Geophys., 53, 481-544, https://doi.org/10.1002/2015RG000481, 2015.

Li, X.: Integrated hydrometeorological - snow - frozen ground observations in the alpine region of the Heihe River Basin, China, Cold and Arid Regions Science Data Center at Lanzhou (CARD), https://doi.org/10.3972/hiwater.001.2019.db, 2019. 
Li, G., Wang, Z. S., and Huang, N.: A Snow Distribution Model Based on Snowfall and Snow Drifting Simulations in Mountain Area, J. Geophys. Res.-Atmos., 123, 7193-7203, https://doi.org/10.1029/2018JD028434, 2018.

Li, H., Wang, J., and Hao, X.: Role of blowing snow in snow processes in Qilian Mountainous region, Sci. Cold Arid Reg., 6, 124-130, https://doi.org/10.3724/SP.J.1226.2014.00124, 2014.

Li, H.-Y. and Wang, J.: Simulation of snow distribution and melt under cloudy conditions in an Alpine watershed, Hydrol. Earth Syst. Sci., 15, 2195-2203, https://doi.org/10.5194/hess-15-21952011, 2011.

Li, X., Li, X. W., Li, Z. Y., Ma, M. G., Wang, J., Xiao, Q., Liu, Q., Che, T., Chen, E. X., Yan, G. J., Hu, Z. Y., Zhang, L. X., Chu, R. Z., Su, P. X., Liu, Q. H., Liu, S. M., Wang, J. D., Niu, Z., Chen, Y., Jin, R., Wang, W. Z., Ran, Y. H., and Xin, X.: Watershed Allied Telemetry Experimental Research, J. Geophys. Res.-Atmos., 114, D22103, https://doi.org/10.1029/2008JD011590, 2009.

Li, X., Cheng, G. D., Liu, S. M., Xiao, Q., Ma, M. G., Jin, R., Che, T., Liu, Q. H., Wang, W. Z., Qi, Y., Wen, J. G., Li, H. Y., Zhu, G. F., Guo, J. W., Ran, Y. H., Wang, S. G., Zhu, Z. L., Zhou, J., Hu, X. L., and Xu, Z. W.: Heihe Watershed Allied Telemetry Experimental Research (HiWATER): Scientific Objectives and Experimental Design, B. Am. Meteorol. Soc., 94, 1145-1160, https://doi.org/10.1175/BAMS-D-12-00154.1, 2013.

Li, X., Liu, S. M., Xiao, Q., Ma, M. G., Jin, R., Che, T., Wang, W. Z., Hu, X. L., Xu, Z. W., Wen, J. G., and Wang, L. X.: A multiscale dataset for understanding complex eco-hydrological processes in a heterogeneous oasis system, Sci. Data, 4, 170083, https://doi.org/10.1038/sdata.2017.83, 2017.

Li, X., Cheng, G. D., Lin, H., Cai, X. M., Fang, M., Ge, Y. C., Hu, X. L., Chen, M., and Li, W. Y.: Watershed system model: The essentials to model complex human-nature system at the river basin scale, J. Geophys. Res.-Atmos., 123, 3019-3034, https://doi.org/10.1002/2017JD028154, 2018a.

Li, X., Cheng, G., Ge, Y., Li, H., Han, F., Hu, X., Tian, W., Tian, Y., Pan, X., Nian, Y., Zhang, Y., Ran, Y., Zheng, Y., Gao, B., Yang, D., Zheng, C., Wang, X., Liu, S., and Cai, X.: Hydrological Cycle in the Heihe River Basin and Its Implication for Water Resource Management in Endorheic Basins, J. Geophys. Res.Atmos., 123, 890-914, https://doi.org/10.1002/2017JD027889, 2018 b.

Liu, S., Li, X., Xu, Z., Che, T., Xiao, Q., Ma, M., Liu, Q., Jin, R., Guo, J., Wang, L., Wang, W., Qi, Y., Li, H., Xu, T., Ran, Y., Hu, X., Shi, S., Zhu, Z., Tan, J., Zhang, Y., and Ren, Z.: The Heihe Integrated Observatory Network: A Basin-Scale Land Surface Processes Observatory in China, Vadose Zone J., 17, 180072, https://doi.org/10.2136/vzj2018.04.0072, 2018.

Liu, S. M., Xu, Z. W., Wang, W. Z., Jia, Z. Z., Zhu, M. J., Bai, J., and Wang, J. M.: A comparison of eddy-covariance and large aperture scintillometer measurements with respect to the energy balance closure problem, Hydrol. Earth Syst. Sci., 15, 1291-1306, https://doi.org/10.5194/hess-15-1291-2011, 2011.

Morin, S., Lejeune, Y., Lesaffre, B., Panel, J.-M., Poncet, D., David, P., and Sudul, M.: An 18-yr long (1993-2011) snow and meteorological dataset from a mid-altitude mountain site (Col de Porte, France, $1325 \mathrm{~m}$ alt.) for driving and evaluating snowpack models, Earth Syst. Sci. Data, 4, 13-21, https://doi.org/10.5194/essd4-13-2012, 2012.
Nayak, A., Marks, D., Chandler, D. G., and Seyfried, M.: Long-term snow, climate, and streamflow trends at the Reynolds Creek Experimental Watershed, Owyhee Mountains, Idaho, United States, Water Resour. Res., 46, 79-89, https://doi.org/10.1029/2008WR007525, 2010.

Pellerin, B. A., Saraceno, J. F., Shanley, J. B., Sebestyen, S. D., Aiken, G. R., Wollheim, W. M., and Bergamaschi, B. A.: Taking the pulse of snowmelt: in situ sensors reveal seasonal, event and diurnal patterns of nitrate and dissolved organic matter variability in an upland forest stream, Biogeochemistry, 108, 183-198, https://doi.org/10.1007/s10533-011-9589-8, 2012.

Peng, H., Zhao, C., Feng, Z., Xu, Z., Wang, C., and Zhao, Y.: Canopy interception by a spruce forest in the upper reach of Heihe River basin, Northwestern China, Hydrol. Process., 28, 1734-1741, https://doi.org/10.1002/hyp.9713, 2014.

Peng, X., Zhang, T., Cao, B., Wang, Q., Wang, K., Shao, W., and Guo, H.: Changes in freezing-thawing index and soil freeze depth over the Heihe River Basin, western China, Arct. Antarct. Alp. Res., 48, 161-176, https://doi.org/10.1657/AAAR00C-13-127, 2016.

Pomeroy, J., Bernhardt, M., and Marks, D.: Research network to track alpine water, Nature, 521, 32-32, https://doi.org/10.1038/521032c, 2015.

Pomeroy, J. W., Gray, D. M., Brown, T., Hedstrom, N. R., Quinton, W. L., Granger, R. J., and Carey, S. K.: The cold regions hydrological process representation and model: a platform for basing model structure on physical evidence, Hydrol. Process., 21, 2650-2667, https://doi.org/10.1002/hyp.6787, 2007.

Schmugge, T. J., Kustas, W. P., Ritchie, J. C., Jackson, T. J., and Rango, A.: Remote sensing in hydrology, Adv. Water Resour., 25, 1367-1385, https://doi.org/10.1016/S0309-1708(02)000659, 2002.

Shanley, J. B. and Chalmers, A.: The effect of frozen soil on snowmelt runoff at Sleepers River, Hydrol. Process., 13, 1843-1857, https://doi.org/10.1002/(SICI)10991085(199909)13:12/13<1843::AID-HYP879>3.0.CO;2-G, 1999.

Streletskiy, D., Biskaborn, B., Smith, S., Noetzli, J., Viera, G., and Schoeneich, P.: Strategy and Implementation Plan 2016-2020 for the Global Terrestrial Network for Permafrost (GTN-P), The George Washington University, Washington D.C., 42 pp., 2017.

Walvoord, M. A. and Kurylyk, B. L.: Hydrologic Impacts of Thawing Permafrost - A Review, Vadose Zone J., 15, https://doi.org/10.2136/vzj2016.01.0010, 2016.

Wang, C., Zhao, C., Xu, Z., Wang, Y., and Peng, H.: Effect of vegetation on soil water retention and storage in a semi-arid alpine forest catchment, J. Arid Land, 5, 207-219, https://doi.org/10.1007/s40333-013-0151-5, 2013.

Wang, J., Li, H., and Hao, X.: Responses of snowmelt runoff to climatic change in an inland river basin, Northwestern China, over the past 50 years, Hydrol. Earth Syst. Sci., 14, 1979-1987, https://doi.org/10.5194/hess-14-1979-2010, 2010.

Wang, L., Koike, T., Yang, K., Jin, R., and Li, H.: Frozen soil parameterization in a distributed biosphere hydrological model, Hydrol. Earth Syst. Sci., 14, 557-571, https://doi.org/10.5194/hess14-557-2010, 2010.

Webb, R. W.: Using ground penetrating radar to assess the variability of snow water equivalent and melt in a mixed canopy 
forest, Northern Colorado, Front. Earth Sci., 11, 482-495, https://doi.org/10.1007/s11707-017-0645-0, 2017.

Yang, D., Gao, B., Jiao, Y., Lei, H., Zhang, Y., Yang, H., and Cong, Z.: A distributed scheme developed for eco-hydrological modeling in the upper Heihe River, China-Earth Sci., 58, 36-45, https://doi.org/10.1007/s11430-014-5029-7, 2015.
Zhang, Y., Cheng, G., Li, X., Jin, H., Yang, D., Flerchinger, G. N., Chang, X., Bense, V. F., Han, X., and Liang, J.: Influences of Frozen Ground and Climate Change on Hydrological Processes in an Alpine Watershed: A Case Study in the Upstream Area of the Hei'he River, Northwest China, Permafrost Periglac., 28, 420-432, https://doi.org/10.1002/ppp.1928, 2017. 